\title{
IMPRONTAS VEGETALES EN ARQUITECTURA E IMPRONTAS DE CESTERÍA EN EL YACIMIENTO IBÉRICO DEL CERRO DE LA CRUZ (ALMEDINILLA, CÓRDOBA) ${ }^{1}$
}

\author{
VEGETABLE IMPRINTS IN ARCHITECTURE AND BASKETWORK IMPRINTS IN THE IBERIAN SITE \\ OF CERRO DE LA CRUZ (ALMEDINILLA, CÓRDOBA)
}

\author{
JAVIER MORALEJO ORDAX \\ Universidad Autónoma de Barcelona \\ EDUARDO KAVANAGH DE PRADO \\ Universidad Autónoma de Madrid \\ FERNANDO QUESADA SANZ \\ Universidad Autónoma de Madrid
}

\section{INTRODUCCIÓN}

El Cerro de la Cruz es un farallón rocoso de $952 \mathrm{~m}$ de altitud que se encuentra en las estribaciones orientales de las sierras subbéticas, al sur de la provincia de Córdoba. Se sitúa en el extremo oriental de la depresión Priego-Alcaudete, parte de la cual se domina visualmente desde la cima.

Se trata de un emplazamiento (Fig. 1) paradigmático para la ubicación de un poblado protohistórico: sus vertientes septentrional y occidental presentan pendientes muy pronunciadas, mientras que las pendientes sur y este son más suaves, permitiendo la edificación en una superficie de hasta unas cuatro hectáreas, y accesibles para personas,acémilas e incluso vehículos. Con todo, según M. Zamora, el poblado del Cerro de la Cruz se situó en un emplazamiento «de condiciones secundarias (no óptimas) para el desarrollo del hábitat humano» (Zamora, 2010, 61), por su localización en un sitio escarpado de difícil acceso y su lejanía de tierras de cultivo. Por su visibilidad relativamente limitada hacia el sur y este) se convierte en un emplazamiento de «segunda categoría» en este aspecto. No obstante, es reseñable la proximidad del poblado a la ribera del río Almedinilla lo que facilitaría, no sólo el acceso al agua potable de manera permanente, sino también a diversos vegetales, como las cañas que

\footnotetext{
1.Trabajo realizado en el marco del Proyecto de Investigación «Resistencia y asimilación: la implantación romana en la Alta Andalucía. Estudio y musealización del Cerro de la Merced y Cerro de la Cruz Córdoba) y su territorio», (HAR201343683-P), dentro del Programa Estatal de Fomento de la Investigación Científica y Técnica de Excelencia del MINECO. Los autores agradecen las detalladas observaciones y sugerencias realizadas por los evaluadores anónimos, que han sido atendidas en detalle. Cualquier omisión o error que permanezca es responsabilidad de los autores.
}

crecían en sus márgenes, y que fueron utilizadas para la construcción del poblado. A ello dedicaremos las páginas siguientes.

El enclave es el emplazamiento de un destacado yacimiento arqueológico que ha revelado importantes vestigios del período Ibérico Tardío, además de evidencias de otra fase de ocupación de época medieval emiral islámica y otra durante la Guerra Civil de 193639 (Muñiz y Quesada, 2010).

La historia de las excavaciones se remonta a 1867 con una primera expedición llevada a cabo por D. Luis Maraver y Alfaro (Quesada, Moralejo y Kavanagh, 2010, 31-49). Cabe reseñar, sin embargo, que, tanto las campañas de 1983 a 1985, como las llevadas a cabo entre 2006 y 2014, han sacado a la luz uno de los testimonios más representativos del último período de la Cultura Ibérica en Andalucía. Los resultados de las fases de los trabajos arqueológicos en el Cerro de la Cruz están detallados en diversas publicaciones recientes (Vaquerizo, 1990; Vaquerizo, Quesada y Murillo, 2001; Muñiz y Quesada, 2010; Quesada, Muñiz y López, 2014).

En los trabajos de las dos últimas décadas, los únicos bien documentados, se han excavado más de mil metros cuadrados, con una gran área central en la ladera meridional del Cerro, de donde proceden los restos que estudiamos aquí (Fig. 2). Corresponden a un poblado de mediados del s. II a.C., destruido por un incendio generalizado e intencionado, como demuestran los cadáveres mutilados o aplastados por escombros localizados en diversos puntos del área excavada (López Flores, 2010). Las estructuras constructivas, excepcionalmente bien conservadas en muchos puntos, reflejan una urbanística desarrollada con manzanas grandes cuya concepción y distribución sólo puede obedecer a la iniciativa de un poder organizado con una rigurosa planificación (Quesada, Kavanagh y Moralejo, 2010, 87). 


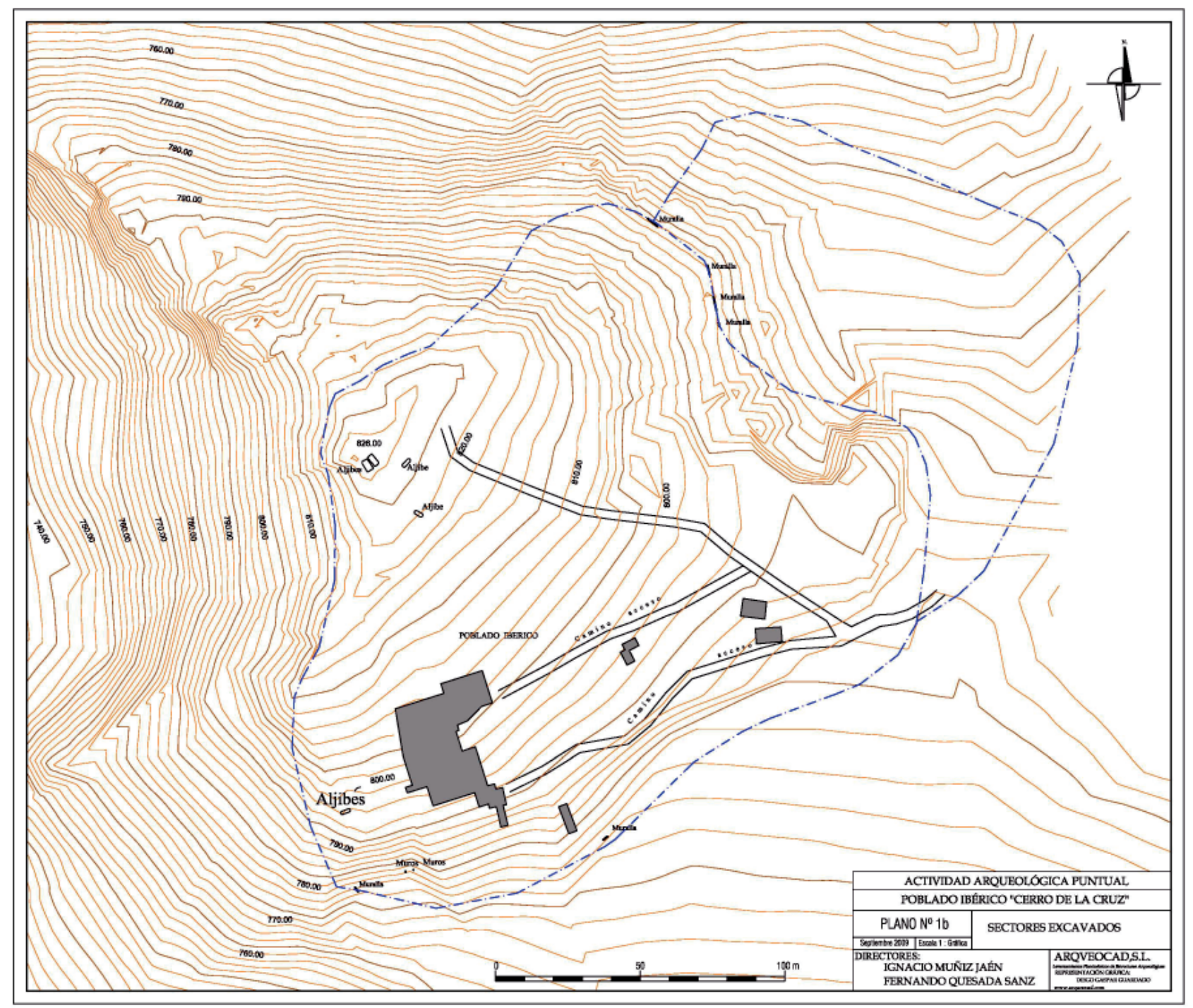

Figura 1: Planimetría del Cerro de la Cruz.

Los edificios derrumbados y abrasados albergan las trazas de la vida diaria, incluyendo una gran cantidad de molinos, algunos de ellos en uso en el momento de la destrucción (Quesada, Kavanagh y Lanz, 2014) y otros muchos elementos. Las estructuras de habitación se agrupan en manzanas amplias con numerosos espacios interconectados, formando módulos más o menos regulares, con dos pisos más sótano y azotea, que incluyen almacenes con decenas de ánforas, algunas todavía con grano quemado. Sobre zócalos de mampostería de entre medio y un metro de ancho se alzan potentes muros de adobe o tapial concebidos para soportar grandes pesos, y entre los derrumbes se documentan restos de vigas quemadas, algunas ya analizadas (vid. infra), y elementos de suelos y cubiertas con improntas vegetales, algunas cocidas por el calor del incendio.

La importancia del yacimiento ibérico del Cerro de la Cruz viene dada por su buena datación entre c. 150/140 a.C., su excelente estado de conservación, su urbanística y edilicia y los numerosos materiales hallados in situ. El conjunto nos proporciona una de las mejores muestras de la vida de las poblaciones de la Alta Andalucía en la Baja Época Ibérica. Por otra parte, su final violento y la sugerente evidencia arqueológica que de ello se ha conservado, nos muestra a las claras que el proceso de romanización de lo que, más tarde, sería la Bética, no se produjo, ni mucho menos, de manera uniforme en todos los espacios del ámbito ibérico.

\section{VEGETACIÓN Y RECURSOS EN EL ENTORNO CERCANO}

No es novedoso señalar que las poblaciones ibéricas, durante la II Edad del Hierro recurrieron a los recursos naturales más próximos al emplazamiento donde eligieran habitar a la hora de edificar sus asentamientos, así como para elaborar gran parte de los elementos que componían su cultura material. Al no tratarse de grandes estructuras centralizadas 


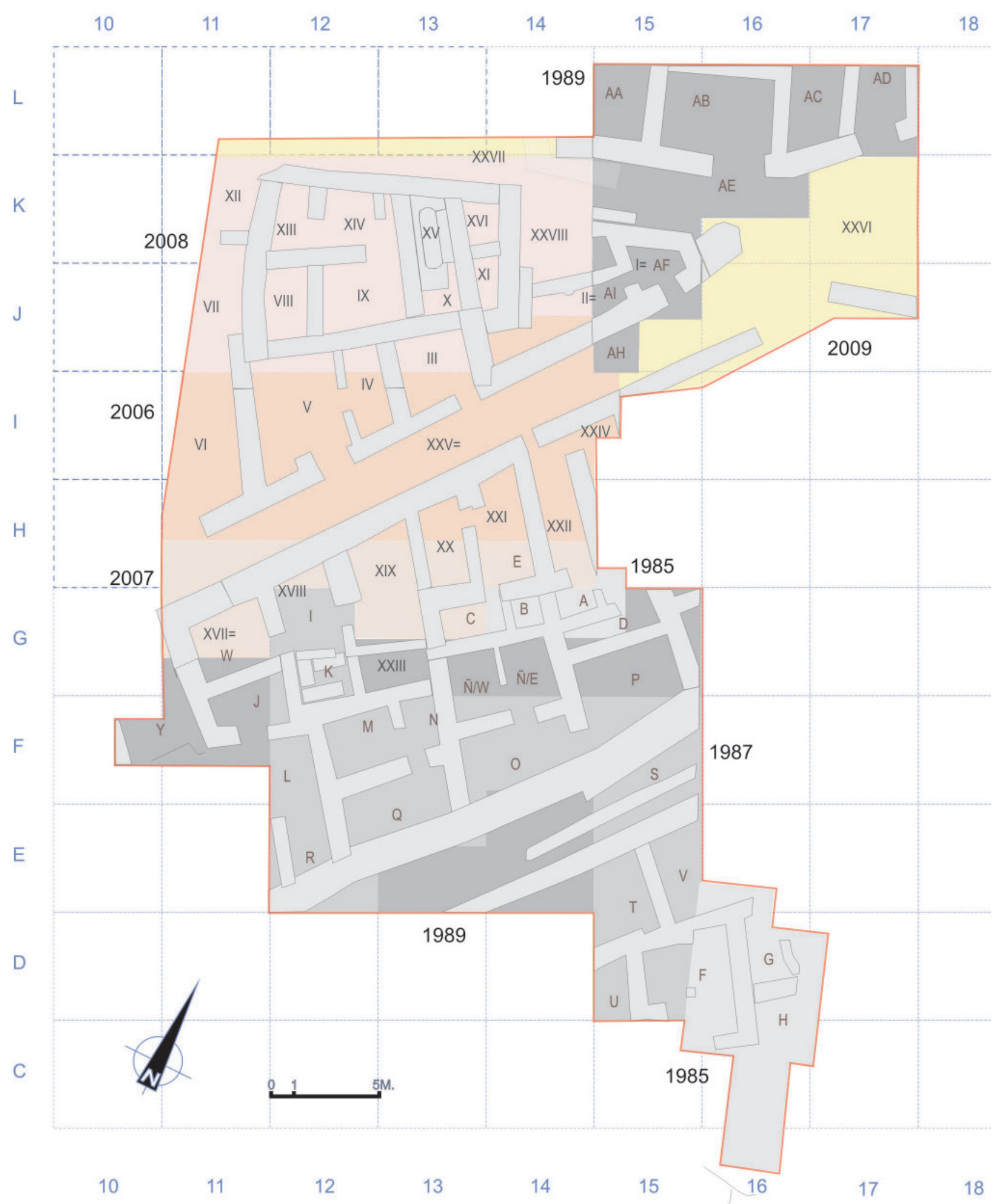

Figura 2: Plano del área central excavada en el área central del Cerro de la Cruz entre 1985 y 2009. 
como los grandes reinos del Mediterráneo Antiguo, los pueblos íberos sufrían limitaciones a la hora de localizar, extraer, transportar y trabajar los recursos necesarios para la construcción de un hábitat apropiado para el desarrollo de la vida sedentaria en comunidad, sustentada por las actividades agropecuarias. Algunos estudios destacados muestran que los íberos debían controlar un territorio circundante de, como mínimo, unos $2,5 \mathrm{~km}$ alrededor del emplazamiento del poblado para poder acceder a los recursos necesarios (Mata y Pérez Jordá, 2000; Bonet, Díes y Rubio, 2000, 431-439).

La vegetación actual del Cerro de la Cruz y su entorno es un pálido recuerdo de lo que hubo de ser en época ibérica; la acción secular del hombre ha ido transformando el paisaje hasta convertirlo en el actual en el que la vegetación autóctona fue arrinconada y sustituida por terrenos de cultivo, destacando los olivares que hoy en día lo dominan. No obstante, aun hoy, el entorno del yacimiento cuenta con una notable abundancia de flora, 1200 taxones catalogados y numerosas especies autóctonas andaluzas (Zamora, 2010, 51). El estudio paleo-palinológico realizado sobre una muestra del Cerro de la Cruz ha arrojado resultados de gran interés para la reconstrucción de la flora original (Yañez, 2010, 103-109). El registro obtenido para el contexto del poblado muestra un paisaje dominado por el acebuche, el roble y el alcornoque, acompañados, y esto directamente relacionado con este estudio, con una vegetación de ribera constatada de sauces, alisos, chopos y cañaveral. Asimismo, es reseñable también la presencia de zonas de cultivo en torno al yacimiento, fundamentalmente cereales, leguminosas, vid y praderas nitrófilas con cardos, margaritas, amapolas y gramíneas, además de romero, lavanda y otros arbustos de la misma familia. La presencia de cañaveral (en este caso fundamentalmente de la especie Arundo donax, conocido como cañizo o caña común; y de la especie Pragmites australis, también conocido como carrizo) junto con sauces y chopos confirma que el entorno disponía de los recursos vegetales necesarios para la construcción de cubiertas arquitectónicas, tal y como atestiguan los hallazgos arqueológicos, según veremos.

Los estudios realizados sobre la construcción en madera en la Protohistoria peninsular señalan que las cubiertas precisaban vigas apropiadas; pues no todos los troncos servían para construir el armazón que sostenía la techumbre; parece que en todo el territorio ibérico se optaba por maderos ligeros y largos como los que proporcionan precisamente el chopo, el aliso y el sauce (Asensio, 1995, 41; Maluquer et alii, 1986, 20), además del pino carrasco documentado en otros yacimientos levantinos y también documentado en el Cerro de la Cruz, aunque este terma no nos ocupará aquí. Constituye una referencia especialmente relevante el trabajo de D. Duque sobre los restos antracológicos y el empleo de diversos tipos de maderas como elementos constructivos en la Prehistoria y Protohistoria Peninsulares (Duque, 2004a; 2004b; 2005, etc). En particular, los análisis de este investigador sobre diversas muestras de yacimientos extremeños, muestran el empleo de otras variedades vegetales distintas de las más comunes en la documentación tradicional a la hora de elaborar techumbres y otras estructuras lígneas, como la encina y el pino (especialmente: Duque, 2004a, cap. 2, 39-59; cap. 4, 105-207; cap. 5, 207-539).

En este sentido, los análisis antracológicos realizados en el Cerro de la Cruz sobre muestras de madera carbonizada, a cargo de A. Caperos y M.T. López de Roma, del INIA (ver síntesis en Vaquerizo, Quesada y Murillo, 2001, 98) han permitido la identificación en el Cerro de la Cruz de vigas y elementos de roble (Quercus pyrenaica.), chopo (Populus sp.), fresno (Fraxinus excelsior, L.), Encina o coscoja (Quercux ilex sp. o Quercus coccifera, L.) y pino silvestre o negral (Pinus sylvestris L. o Pinus nigra). Como se aprecia, el análisis antracológico es muy consistente con los resultados palinológicos. Dichos restos revelan el empleo de maderas diversas como elementos constructivos destinados fundamentalmente a tejados, ventanas y puertas, y a vigas cuyos mechinales se han conservado en algún caso en el Cerro de la Cruz, aunque no es este el objetivo de este estudio.

Por otra parte, hemos de tener en cuenta la variabilidad de soluciones de cubiertas que debió emplearse en los edificios del Cerro de la Cruz, como relleno para envigados de madera, encañizado de altillos o semipisos o, simplemente, «sombrajos» para colocar por encima de las azoteas planas a fin de resguardarse del sol. Todas estas soluciones podrían estar reflejadas en las improntas sobre adobe que vamos a estudiar, sin olvidar la marca que las propias vigas de madera dejaban a menudo sobre la capa de barro que sostenían. En este sentido, resulta oportuno realizar alguna observación sobre los dos tipos de vegetación principales documentados, por sus trazas, en los fragmentos de adobe: el cañizo y el carrizo. Considerado como especie, el cañizo recibe la denominación científica de Arundo donax y es conocido también como: caña común, cañavera, bardiza o caña silvestre. Se trata, al parecer, de una especie alóctona, que prolifera en suelos húmedos y actualmente se encuentra presente en la práctica totalidad del territorio peninsular, siendo los pantanos y riberas los espacios más propicios para su reproducción. Por otra parte el género Phragmites, conocido vulgarmente como carrizo, es una variedad que se caracteriza por el menor diámetro de sus tallos y su floración, de las cañas comunes o cañizo. Se trata de una planta perenne, de considerable robustez y de tallos rígidos, gruesos y duros, que pueden llegar a alcanzar los $3 \mathrm{~m}$ de altura, resultando, por tanto, óptimos para su aprovechamiento como material constructivo. El carrizo suele crecer en suelos húmedos con aguas de escasa profundidad, cenagales, al igual que en las riberas, donde forman matas espesas y apretadas 
fácilmente reconocibles (Sanz, Dana y Sobrino 2004; ver su inserción en el Catálogo de especies alóctonas, en el Anejo al Real Decreto 630/2013, de 2 de agosto, $B O E$ n. 185, 03-02-2013, Anejo en páginas 56782 y ss.). Dicho esto, conviene aclarar que, a lo largo de este trabajo nos referiremos en adelante al cañizo como «caña» o «caña común» y emplearemos el término «cañizo» sólo en otra de sus acepciones: la de un entramado de tallos secos de caña y carrizo, característico del utillaje de poblaciones prehistóricas para la elaboración de diversos tipos de cubiertas vegetales. La diferencia entre caña y carrizo es apenas perceptible en el contexto de la arquitectura ibérica, y menos sobre vestigios que sólo son improntas de ellos, no obstante, nos referiremos a aspectos útiles para distinguirlos eventualmente, como el diámetro y la presencia de huellas de fibras, cuando esto sea posible.

\section{CATÁLOGO Y ANÁLISIS DE LAS IMPRONTAS VEGETALES DEL CERRO DE LA CRUZ}

Este estudio describe y analiza un total de 14 muestras. Todas ellas-excepto la n.12 del catálogo-consistentes en fragmentos de barro o adobe sobre los que han quedado impresas trazas de distintos elementos vegetales que se emplearon en la construcción de las estructuras arquitectónicas del poblado del Cerro de la Cruz, así como en la fabricación del utillaje básico de sus moradores. Cabe señalar que entendemos «muestra» como una unidad de análisis que puede estar compuesta por uno o más de estos fragmentos o piezas, determinada por el contexto arqueológico en el que estas últimas hayan aparecido. De esta manera, hemos optado por agrupar las piezas por muestras, $\mathrm{y}$ estas por unidades estratigráficas (Fig. 3). El número total de muestras del catálogo es, por tanto de 14, mientras que el número de piezas o individuos asciende a 24 (Fig. 29). Todas las muestras fueron recogidas durante las campañas de excavación de 2006 a 2009 y proceden de contextos estratigráficos fechados a mediados del siglo II a. C. Teniendo en cuenta (a) el tipo de impronta dejada sobre el barro, (b) la existencia o no de trenzado en la huella y (c) el contexto estratigráfico, diferenciamos dos tipos básicos de objeto a estudiar: once muestras que pertenecen a restos de las cubiertas y techumbres, y otras tres que pertenecen a artículos fabricados con cañas y espartos, como esterillas o cestos (Figs. 3 y 4 ).

\begin{tabular}{|c|c|c|c|c|c|c|}
\hline Cat & Ref. ALM & Tipo & $\mathbf{U E}$ & Cuadr. & $\begin{array}{c}\text { Estancia } \\
\text { /muro }\end{array}$ & Observaciones \\
\hline 1 & $06 / 1004 / 011 \mathrm{a}$ & ¿Arquitectónico? & 1004 & I12 & Estancia V & Derrumbe de adobes recocidos \\
\hline 2 & $06 / 1004 / 072$ & Cestería & 1004 & $\mathrm{I} 12$ & Estancia V & Derrumbe de adobes \\
\hline 3 & $06 / 1004 / 073$ & Arquitectónico & 1004 & $\mathrm{I} 12 \mathrm{I} 13$ & & Derrumbe de adobes \\
\hline 4 & 06/1004/074 & Arquitectónico & 1004 & I13 & Calle XXV & Derrumbe de adobes \\
\hline 5 & $06 / 1004 / 075$ & Arquitectónico & 1004 & $\mathrm{I} 11 / \mathrm{I} 14$ & General & Derrumbe de adobes \\
\hline 6 & $07 / 1111 / 352 a$ & Arquitectónico & 1111 & H13, H14 & Estancia XX ó XXI & Tierra gris bajo 1106 \\
\hline 7 & $07 / 1156 / 384 c$ & Arquitectónico & 1156 & H12 & Estancia XVIII & Derrumbe Norte de Dep. V \\
\hline 8 & $08 / 1001 / 466 b$ & Arquitectónico & 1001 & $\mathrm{~J} 12$ & Estancia IX & Superficie \\
\hline 9 & 08/1001/ & Arquitectónico & 1001 & K14 & $\begin{array}{l}\text { Calle XXVII o estancia } \\
\text { XXVIII }\end{array}$ & Superficie \\
\hline 10 & $08 / 1233 / 542 a$ & Arquitectónico & 1233 & $\mathrm{~J} 12$ & Estancia IV & $\begin{array}{l}\text { Derrumbe amarillento al S de UC } \\
1237\end{array}$ \\
\hline 11 & $08 / 1233 / 542 d$ & Arquitectónico & 1233 & $\mathrm{~J} 12$ & Estancia IV & $\begin{array}{l}\text { Derrumbe amarillento al S de UC } \\
1237\end{array}$ \\
\hline 12 & $08 / 1264 / 660 \mathrm{f}$ & $\begin{array}{l}\text { Entramado } \\
\text { Cestería }\end{array}$ & 1264 & $\mathrm{~J} 13$ & Estancia III & $\begin{array}{l}\text { Derrumbe ibérico al S de zapata } \\
\text { NE }\end{array}$ \\
\hline 13 & $06 / 1004 / 073$ & Arquitectónica & 1004 & I12-I13 & - & Derrumbe de adobes \\
\hline 14 & $08 / 1341 / 729 b$ & $\begin{array}{l}\text { Entramado } \\
\text { esparto }\end{array}$ & 1341 & J13-I13 & Estancia III & Nivel de uso de suelo ibérico \\
\hline
\end{tabular}

Figura 3: Resumen del catálogo de muestras. 


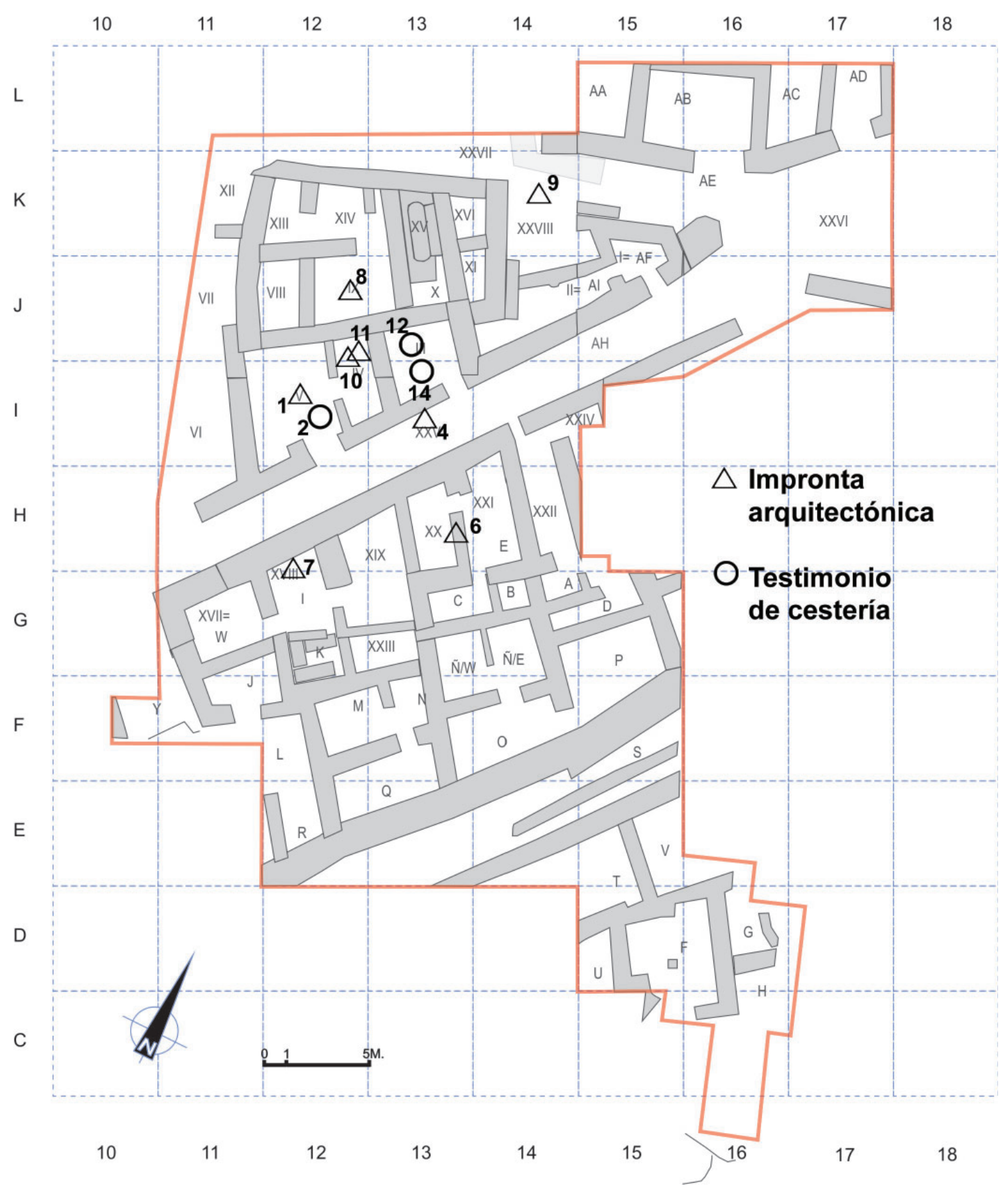

Figura 4: Plano de distribución de hallazgos de improntas del Cerro de la Cruz (2006-2009). 


\section{CATÁLOGO DE IMPRONTAS}

N. CAT. 1 (Fig. 5). N. bolsa: 11 ${ }^{\mathrm{a}}$. N. Registro: 2639. Unidad Estratigráfica: 1014.

Localización: Cuadrícula: I12 Estancia: V. N. ejemplares: 1 . Medidas: $32 X 28 \mathrm{~cm}$.

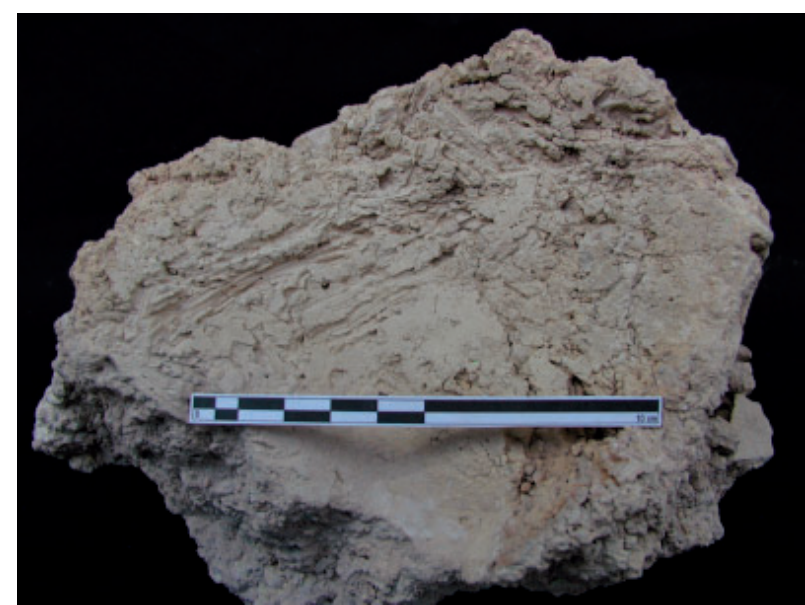

Figura 5: Impronta n. cat. 1.

Descripción y análisis: Muestra de material de derrumbe compactado que presenta, en una de sus caras, la impronta de haces fibras vegetales de difícil interpretación, dispuestas de forma aparentemente desordenada. Las trazas son apenas dos huellas, aunque la profundidad del surco es notable y parte es curva. La

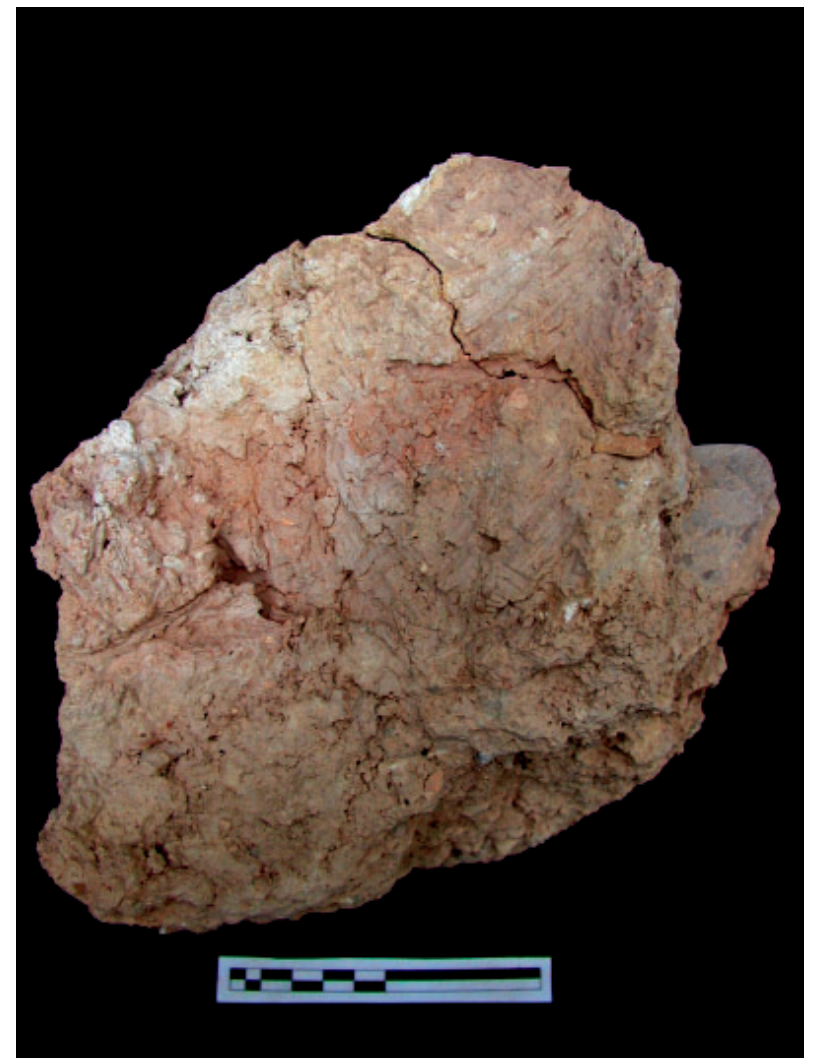

Figura 6: Impronta n. cat. 2 pieza se extrajo de un estrato de derrumbe de los muros de adobe de la estancia V. Observando la fotografía con detalle, cabe destacar que se ha conservado algún fragmento de paja o de caña muy fina incrustada en su superficie. No se trata de esparto, o al menos no de esparto trenzado. En consecuencia, lo clasificamos como improntas de fibra vegetal flexible procedente, por el contexto estratigráfico, de un piso alto o azotea. De hecho, la muestra procede de la misma unidad estratigráfica que restos humanos aplastados (López, 2010, 99, Fig. 5), entre escombros de adobe y barro endurecido.

N. CAT. 2 (Figs. 6 y 7). N. bolsa: 72. N. Registro: 2630. UE: 1004.

Localización: Cuadrícula: I12. Estancia: V.

N. de ejemplares: 2 . Medidas: $15 X 10 ; 12 X 11 \mathrm{~cm}$.

Descripción y análisis: Dos bloques con improntas de cestería, el primero de ellos contiene dos improntas, el segundo una. Se trata de tramas idénticas entre sí, probablemente pertenecientes a un mismo objeto, que muestran un patrón de entramado en sargas de $2 \times 2$. En una de las improntas se aprecia el borde del objeto impreso, donde los ramales que forman la pleita giran $90^{\circ}$, generando con ello un límite.
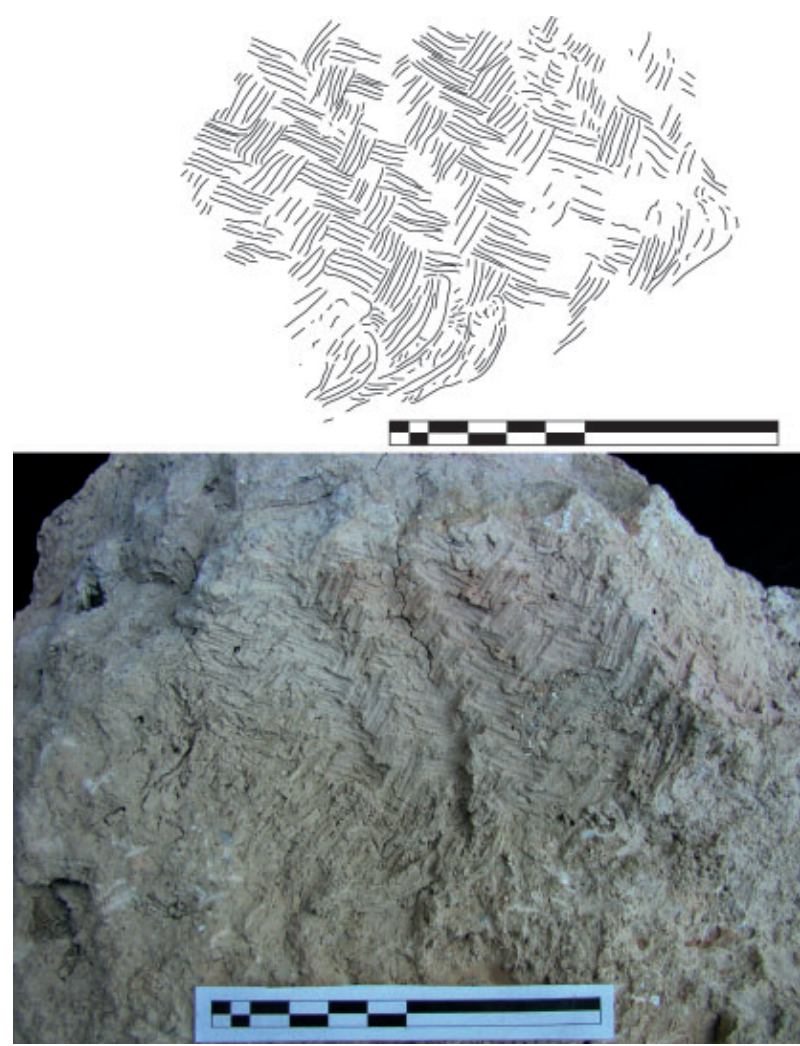

Figura 7: Impronta cat. n. 2 Fotografía y dibujo de la muestra de impronta de cestería sobre tierra. El entramado en sarga $2 \times 2$ es claramente perceptible. Nótese también el giro de ramales en la parte inferior de la impronta, delatando el cierre de la pleita en ese punto. 
N. CAT. 3 (Figs. 8-9). N. bolsa: 73. N. Registro: 2631. UE 1004.

Localización: cuadrícula: I12-I13.

Número de ejemplares: 2.

Descripción y análisis: Dos fragmentos de adobe endurecidos por el fuego, ambos son de morfología irregular al tratarse de restos probablemente pertenecientes al derrumbe ocasionado por el desplome de la techumbre de una de las unidades de habitación de época ibérica situadas en la manzana central del área excavada del poblado (Fig. 4). Las dos piezas fueron halladas en la UE 1004 que corresponde a un derrumbe de adobes situado encima del nivel de uso del suelo ibérico.

a) La primera de ellas, la de mayor tamaño, tiene claras trazas o huellas de paja de pequeño grosor, impresas en casi toda la superficie. Asimismo, en su parte superior izquierda, presenta una pequeña parte carbonizada por acción del incendio ocurrido en el Cerro. Las improntas no presentan ningún tipo de disposición ni trama, y son de grosor y diámetro muy reducido. Estos dos rasgos, unidos a su forma y considerable grosor, nos llevan a interpretar la pieza como un resto de módulo de adobe probablemente de un muro de la estancia. Las improntas parecen testimonio de la paja y pequeñas cañas que se empleaban para proporcionar cohesión a los módulos de adobe antes de secarlos, o bien pequeñas cañas que se le adhirieron en el proceso de secado, algo característico de los ambientes

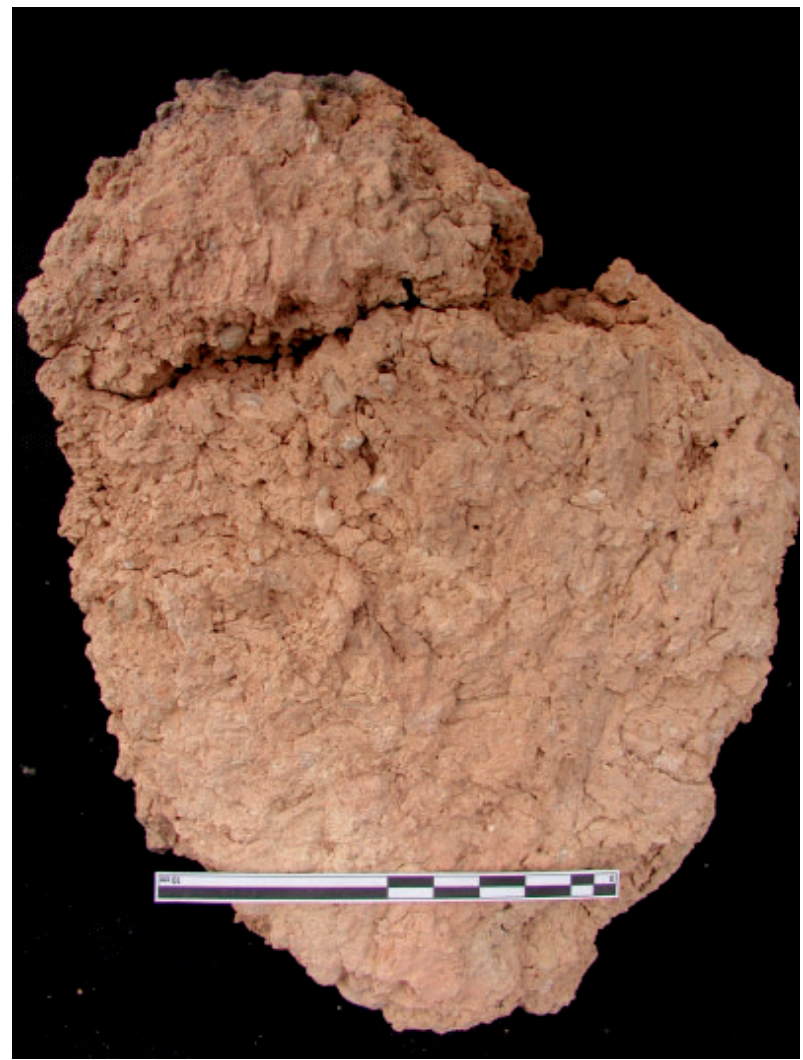

Figura 8: Improntas n. cat. 3.

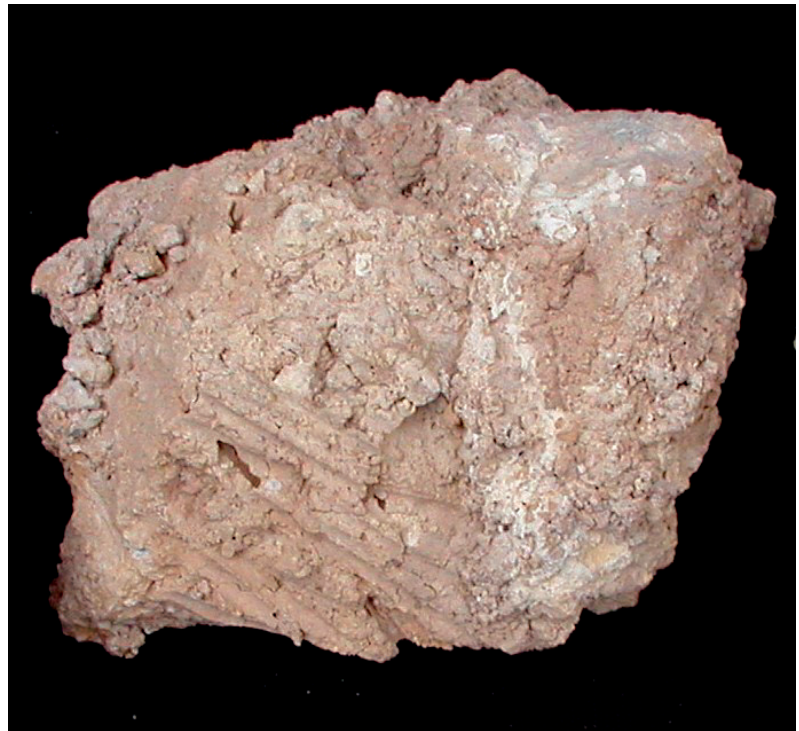

Figura 9: Impronta n. cat. 3

de fabricación de adobe al aire libre. Si observamos la fotografía con detalle podemos apreciar que quedan restos de algún carrizo fino incrustado en el barro endurecido.

b) El segundo fragmento de la muestra presenta huellas, esta vez claras, de cañizo que parece colocado de manera que las cañas estén paralelas y muy juntas las unas con las otras. Cuenta, además, con la particularidad de que conserva restos de cal, material que se utilizaba eventualmente en la construcción de las techumbres, lo que explica las «costras» de color blanquecino que presenta en gran parte de su superficie. Es, asimismo, reseñable la profundidad del surco o lecho de las improntas. Por el tamaño y grosor de la pieza, así como por la disposición y naturaleza de las improntas, podría tratarse de un fragmento de la capa de barro y cal con que se revestía la cubierta vegetal de las casas. El grosor es suficiente para considerarlo así.

\section{N. CAT. 4 (Fig. 10). N. bolsa: 74. N. Registro: 5301.}

\section{$U E: 1004$.}

Localización: cuadrícula: I13. Estancia: XXV (Calle ibérica).

Número de ejemplares: 1 . Medidas: $40 \times 30 \mathrm{~cm}$.

Descripción y análisis: Fragmento de barro endurecido de morfología considerablemente regular, en este caso, cuadrada. Se trata, probablemente, de un módulo de adobe parcialmente conservado. En una de sus caras, la pieza presenta claras trazas de improntas de material vegetal que ocupan toda la superficie, la otra cara está lisa; cabe reseñar la claridad con que se han conservado las improntas. Una vista más detallada nos permite comprobar cómo la disposición de las improntas es, en este caso, irregular, no siguiendo ningún patrón ni orden concreto y que las marcas en negativo son de sección cuadrada y no redonda, por lo que no parecen pertenecer a ningún tipo de caña. Cabe 


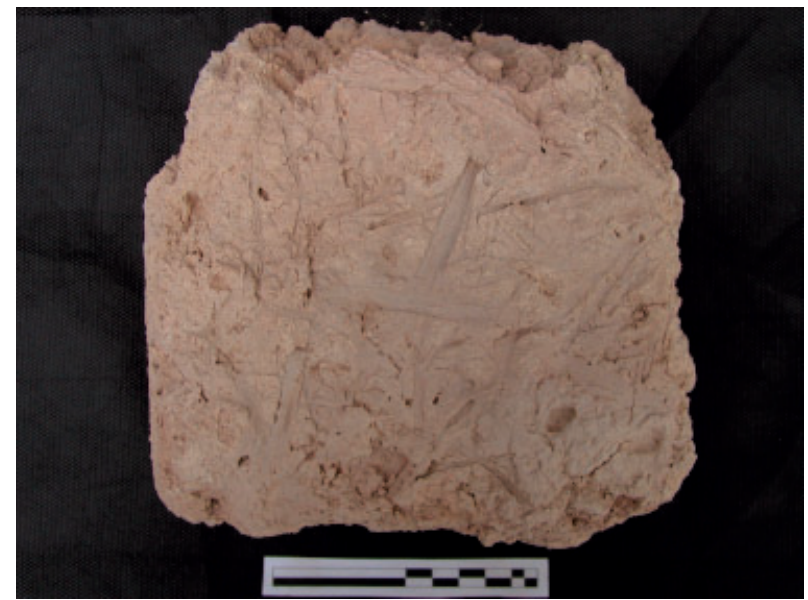

Figura 10: Impronta n. cat. 4.

reseñar un profundo orificio circular practicado en su ángulo inferior derecho. El tipo y disposición de las marcas y el tamaño de la pieza nos hacen pensar en un fragmento de adobe con trazas de paja destinado a un muro. Sin embargo, el hallazgo de esta pieza se produjo en la excavación arqueológica pero pertenece a un gran paquete de derrumbe de adobe que se extiende por un área relativamente grande del yacimiento que cubre varias estancias o unidades de habitación. Por esta razón, no contamos con datos precisos para averiguar si este fragmento perteneció a un muro o a la techumbre de una habitación. A pesar de todo, parece claro que, en este caso, las improntas que vemos son adherencias de paja que dejaron su huella cuando el módulo aún estaba fresco en el lugar de fabricación.

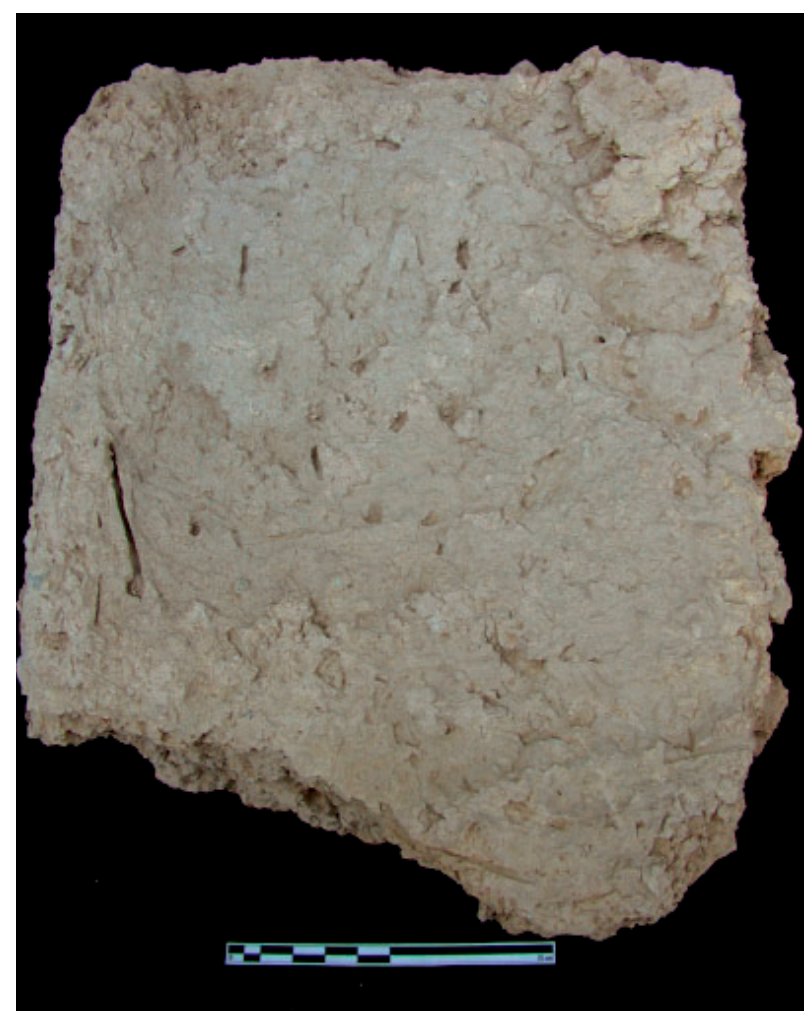

Figura 11: Impronta n. cat. 5.
N. CAT. 5 (Fig. 11). N. bolsa: 75. N. Registro: 5302. UE: 1004.

Localización: cuadrícula sector J14 a I14.

Número de ejemplares: 1 . Medidas: $21 x 26 \mathrm{~cm}$.

Descripción y análisis: Ejemplar de módulo de adobe de formato rectangular conservado parcialmente. La muestra apareció en una unidad estratigráfica correspondiente a un derrumbe de adobes en un nivel superficial. Conservamos casi intacto el margen izquierdo de la pieza que nos da una idea de su factura y morfología original. Toda la superficie de una cara presenta improntas que no forman disposición alguna. Por el diámetro, la profundidad y las trazas de fibras, las huellas parecen ser de briznas de paja y otros vegetales menores. La ausencia total de disposición y la forma y profundidad de las improntas, nos conducen a interpretar las marcas como huellas de material vegetal empleadas en el momento de fabricación de un módulo de adobe destinado probablemente al alzado del muro de una estancia, como la n. 4; así parecen confirmarlo la forma, tamaño y grosor de la pieza.

\section{N. CAT. 6 (Fig. 12). N. bolsa: 352 $2^{\mathrm{a}}$ N. Registro:} 5303. UE: 1111.

Localización: cuadrícula: H13-H14 Estancia: XX/ XXI.

Número de ejemplares: 1. Medidas:14x10 cm.

Descripción y análisis: Pequeño fragmento de morfología irregular con una impronta de sección cuadrangular y bandas paralelas en su parte central. Esta pieza apareció en la estancia XX o XXI en un nivel estratigráfico de tierra grisácea (US-1111). Dicho nivel podría pertenecer a una capa de descomposición de material orgánico como madera y otros vegetales. Es reseñable que su parte superior y su ángulo inferior izquierdo son de forma plana, además, fue hallada en la cara interna del muro oriental de la estancia, y la impronta peculiar que presenta, no es ni de cañas comunes ni de carrizo. Esta pieza podría corresponder a la unión entre la última hilada de piedras de un muro y la primera hilada de adobes. La pieza que vemos sería el primer adobe junto con parte de la

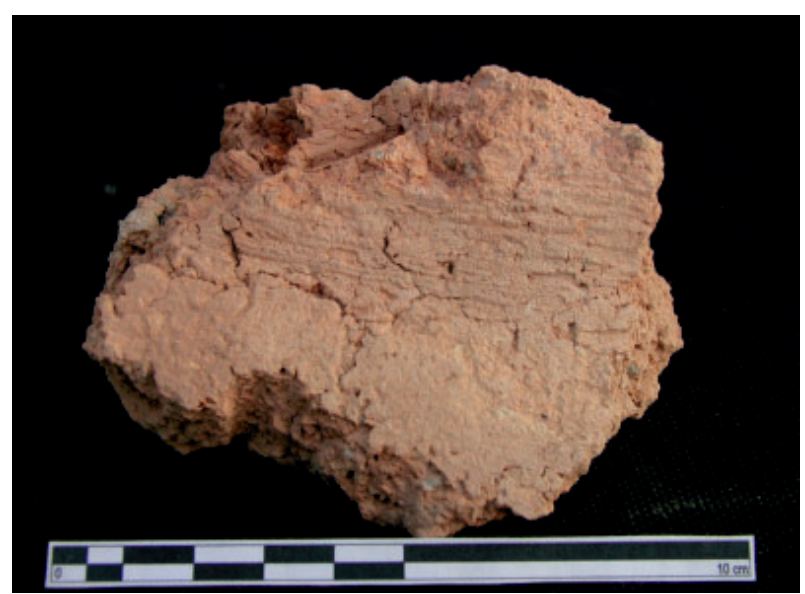

Figura 12: Impronta n. cat. 6. 
argamasa usada para unirlo a una piedra. Esta argamasa tendría mucha paja, que correspondería con el negativo de las improntas que vemos. La forma cóncava de la superficie se explicaría porque la piedra sobre la que se apoyaba era convexa. También podría tratarse del negativo de un elemento lígneo que originalmente estuvo en contacto con la pieza antes de descomponerse. Por lo tanto podría ser interpretada también como un fragmento del revestimiento de barro que se colocaba por encima del envigado de madera junto con el cañizo para cubrir los vanos de la estructura que soportaba la techumbre.

\section{N. CAT. 7 (Fig. 13). N. bolsa: 384c. N. Registro: 5304. Unidad Estratigráfica: 1156.}

Localización: cuadrícula: H12. Estancia: XVIII.

Número de ejemplares: 1 . Medidas: $15 \times 7 \mathrm{~cm}$.

Descripción y análsis: Pequeño fragmento de barro endurecido de morfología irregular. Presenta una cara lisa con restos de cal y otra cara con dos improntas claras de considerable tamaño y sección rectangular, además de vagas trazas de impronta de cañas de pequeño diámetro -que podrían ser de carrizo- en su parte izquierda. La pieza fue exhumada en el interior de la estancia XVIII y pertenece a un paquete de derrumbe de adobe de un muro de la estancia. Las marcas podrían ser huellas en negativo de elementos lígneos, por la superficie, lisa con cal, y la situación y nivel estratigráfico del hallazgo. Podría tratarse de un testimonio de la gruesa capa de adobe y cal que se aplicaba encima del enramado de la techumbre. Al estar en contacto el barro fresco con la madera habría dejado su huella en la parte inferior de dicha capa.

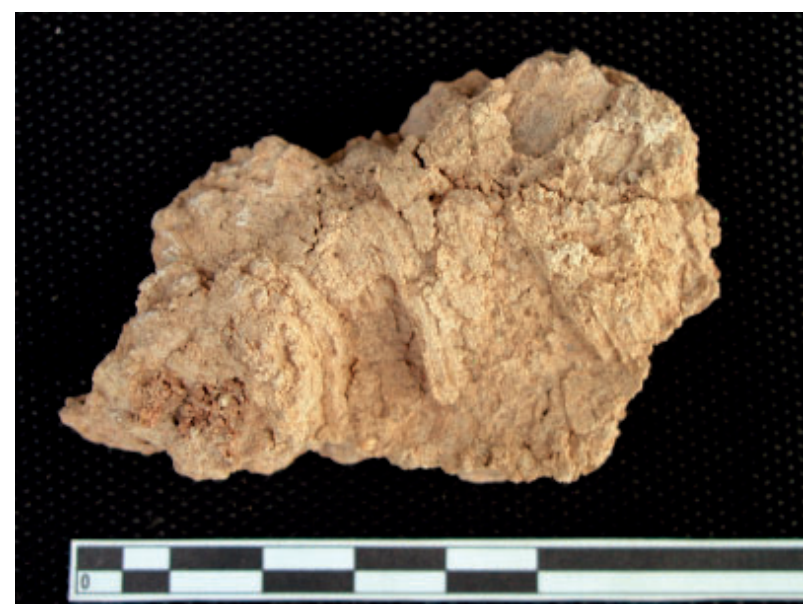

Figura 13: Impronta n. cat. 7.

N. CAT. 8 (Fig. 14). N. bolsa: 466b. N. Registro: 5305. UE: 1156.

Localización: cuadrícula: J12. Estancia: IX. Número de ejemplares: 1 . Medidas: $25,2 \times 23,5 \mathrm{~cm}$. Descripción y análisis: Fragmento de barro recocido de morfología irregular, con visibles improntas de sección circular que la atraviesan longitudinalmente. La muestra estuvo sometida, sin duda, a un calor muy intenso como el de un incendio, de ahí su calcificación parcial y extrema dureza. Apareció en el nivel superficial (UE 1001) en el interior de la estancia número IX, probablemente como un afloramiento parcial de una unidad de derrumbe sita más abajo. Las improntas pertenecen a ramas de cañas gruesas, colocadas en paralelo a lo largo de la pieza. Su sección, claramente circular, considerable diámetro y la presencia de fibras pertenecientes a la corteza, así lo muestran. Estas improntas corresponderían al entramado vegetal de cañizo, cubierto de barro y cal que se colocaba por encima del envigado de madera en las techumbres de las casas ibéricas.

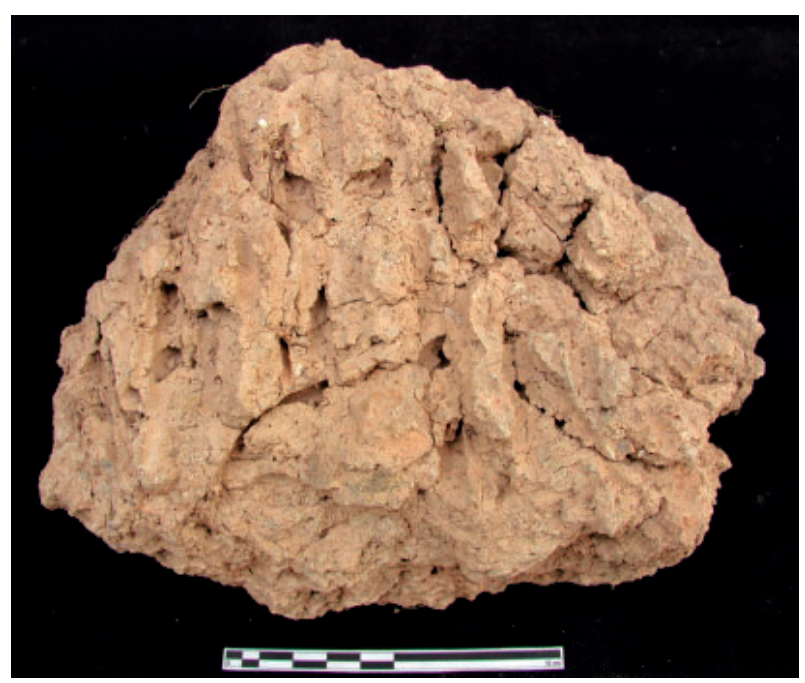

Figura 14: Impronta n. cat. 8.

N. CAT. 9 (Fig. 15). UE 1001.

Localización: cuadrícula: K14. Estancia: XXVIII o XVII.

Número de ejemplares: 1 . Medidas: $37,2 x 23 \mathrm{~cm}$.

Descripción y análisis: Fragmento de barro endurecido de morfología irregular perteneciente a la unidad estratigráfica superficial (US-1001). Apareció en el umbral entre la estancia XXVIII y la calle de la parte norte del área excavada (Fig. 4). Formaba parte de un paquete duro de derrumbe que afloraba hasta el nivel superficial y se retiró al inicio de las excavaciones del sector. Las improntas de esta pieza parecen claras: marcas dispuestas en un entramado que cruza diagonalmente la superficie de la pieza. Dichas improntas se pueden identificar con pajas que estuvieron mezcladas con el propio barro, o bien, con un manojo de elementos vegetales- quizá tallos de carrizo por el grosor- de pequeño tamaño. El hecho de que aparezcan las marcas en una de sus caras, el grosor del fragmento y la disposición en entramado nos llevan a interpretar esta muestra como parte de una de las capas de tierra, agua y paja que se disponían por encima del entramado de madera de la techumbre o de un primer piso. 


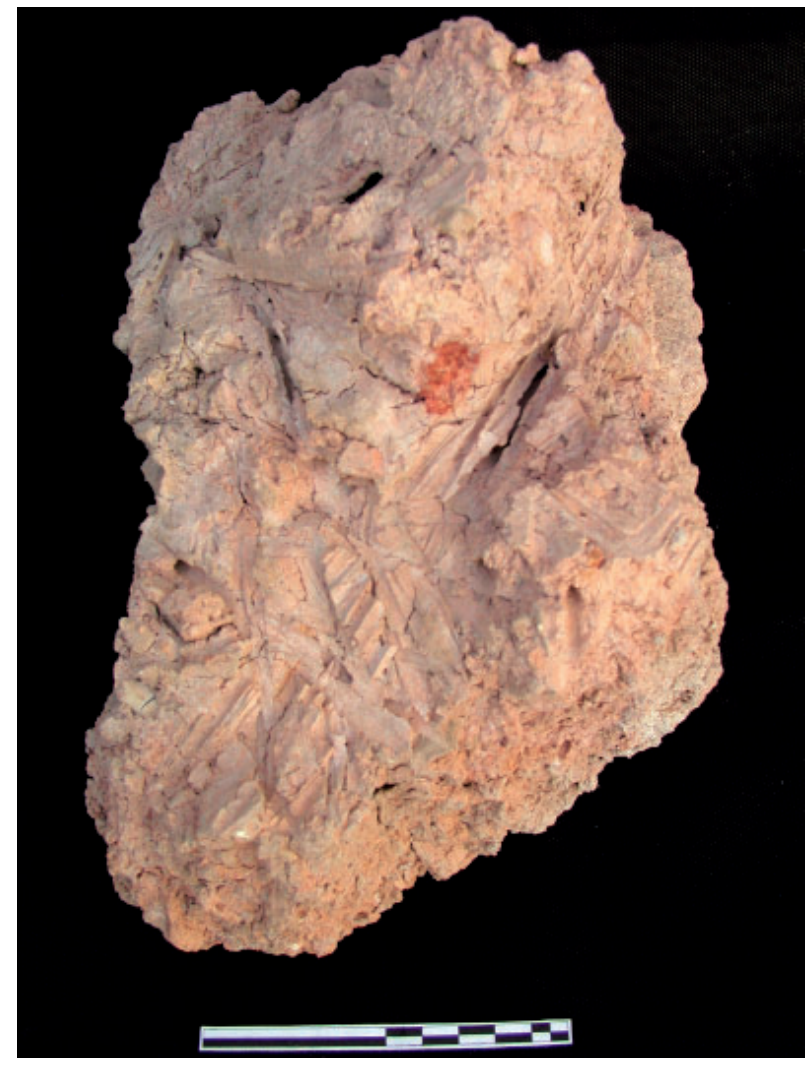

Figura 15: Impronta n. cat. 9.

N. CAT. 10 (Figs. 16-19). N. bolsa: 542a. N. Registro: 5306. UE: 1233.

Localización J12. Estancia: IV. Derrumbe al Sur del muro ibérico UC 1237

Número de ejemplares: 5.

Descripción y análisis: Conjunto de cinco fragmentos de derrumbe de adobe endurecido con improntas de cañizo en la práctica totalidad de sus superficies. Aparecieron como parte de un gran derrumbe de adobe (US-1233) en la estancia IV de uno de los sectores excavados del yacimiento. Este conjunto constituye una de las pruebas más claras que conservamos del empleo de material vegetal en las cubiertas.

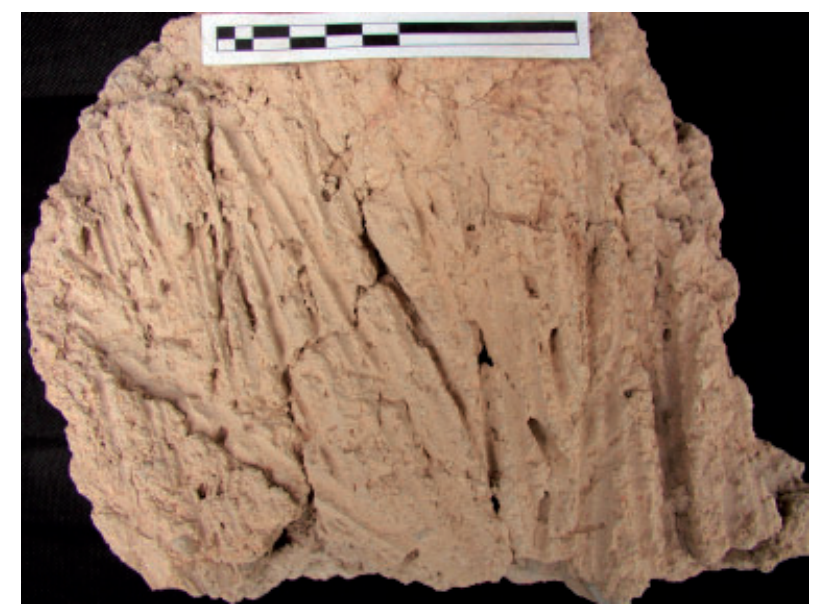

Figura 16: Impronta n. cat. 10.

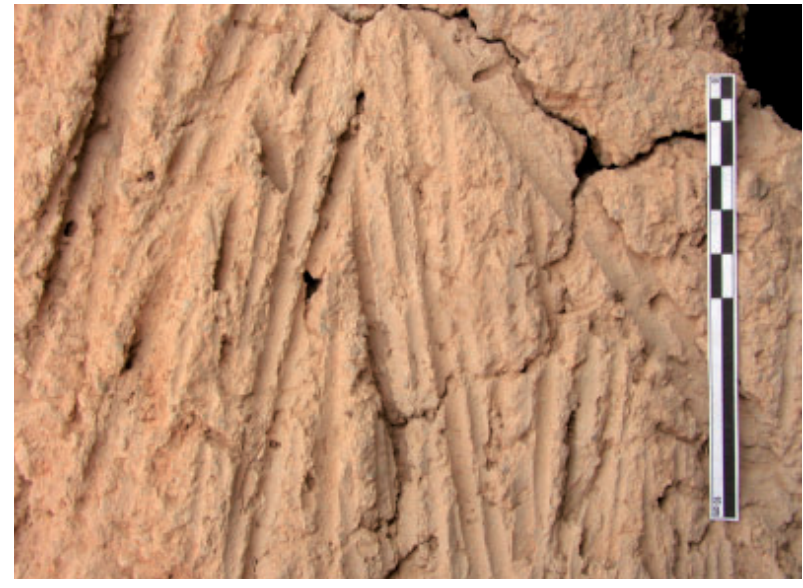

Figura 17: Impronta n. cat. 10.

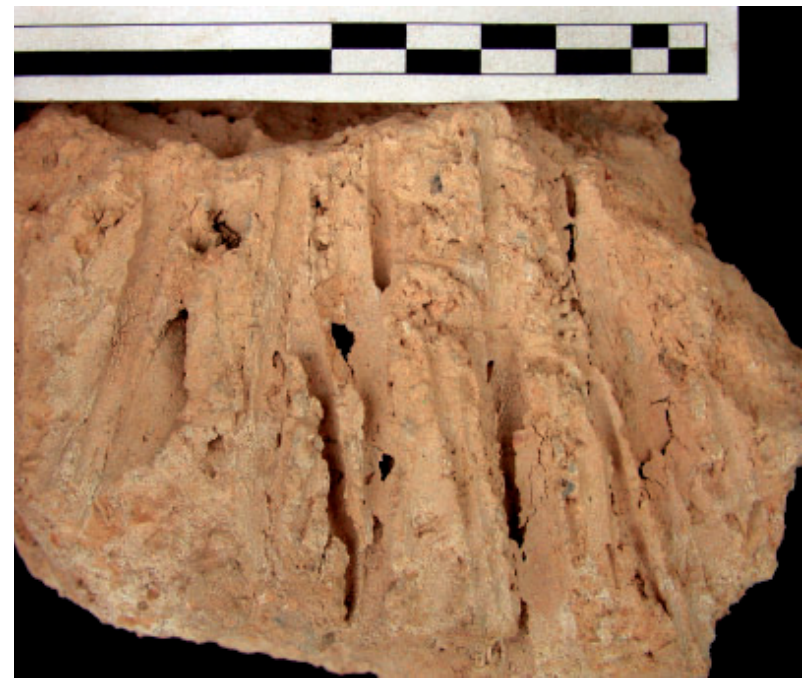

Figura 18: Impronta n. cat. 10

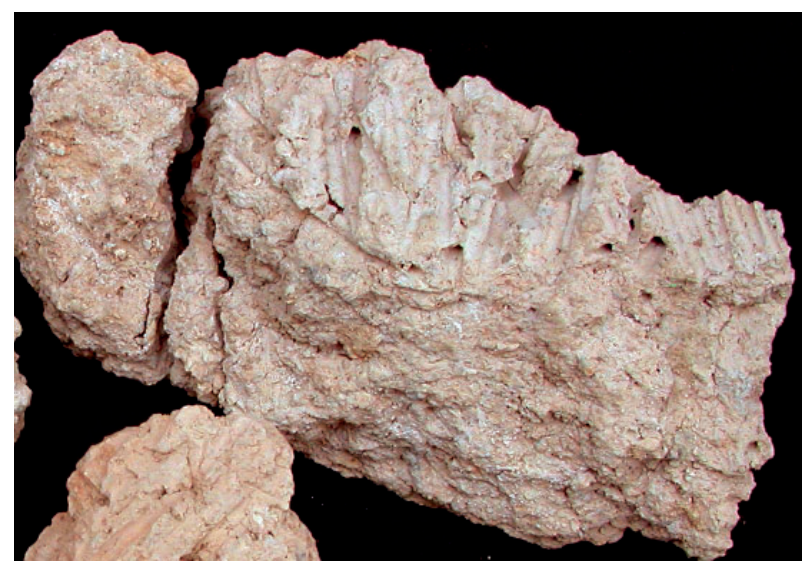

Figura 19: Impronta n. cat. 10.

Las improntas, en este caso muy claras, de tallos de carrizo y alguna de caña más gruesa, tienen un lecho muy marcado y están dispuestas de forma paralela en los adobes. Da la impresión de que en este caso se ha conservado en la huella marcada la disposición original del enramado de la cubierta de dicha estancia (la IV). En todas las piezas, especialmente en dos de ellas, se aprecian trazas de diferente diámetro 
correspondientes a las cañas de tamaño heterogéneo, de caña gruesa y de carrizo de entre 0,7 y $3,2 \mathrm{~cm}$ de grosor, del enramado dispuesto.

Siguiendo estas apreciaciones, podríamos proponer que, en este caso, parece claro que se emplearon cañas de grosor relativamente grande para tapar los huecos del entramado de madera de forma homogénea y que podrían haberse rellenado los huecos entre ellos con carrizos de menor diámetro.

Esta es quizá la muestra más clara de todas las analizadas a nivel arquitectónico y constituye un testimonio fundamental para constatar la fabricación de las techumbres con elementos orgánicos perecederos en el Cerro de la Cruz. Si nos detenemos en el contexto del hallazgo (Fig. 4), un paquete de derrumbe sito por encima del nivel de pavimento ibérico, pero por debajo de una unidad constructiva correspondiente al muro de contención al norte de la estancia (UC-1237), podríamos aventurar que estos restos de impronta podrían haber pertenecido a un semipiso o altillo construido en el interior de la estancia n. IV. En dicha habitación apareció un número muy elevado de pesas de telar calcinadas por el incendio que podría indicarnos su función, al menos parcialmente, como un pequeño centro de producción y almacenamiento.

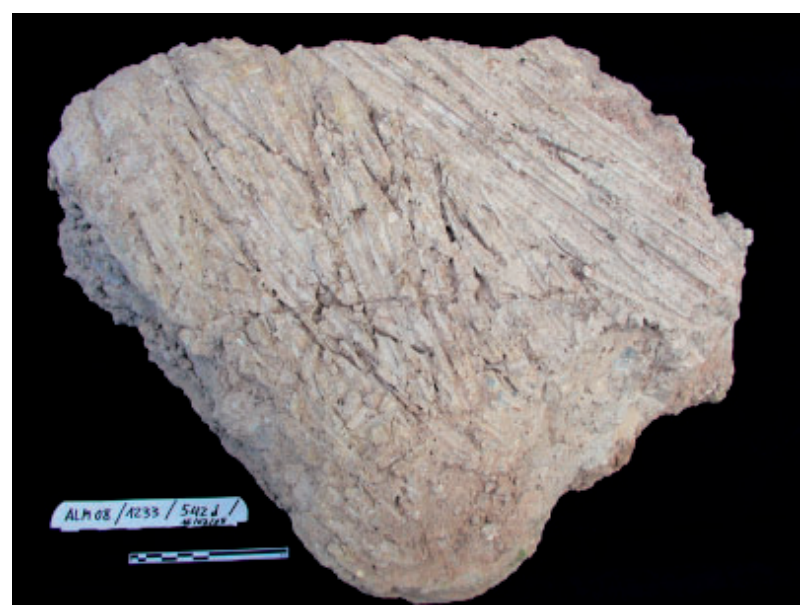

Figura 20: Impronta n. cat. 11.

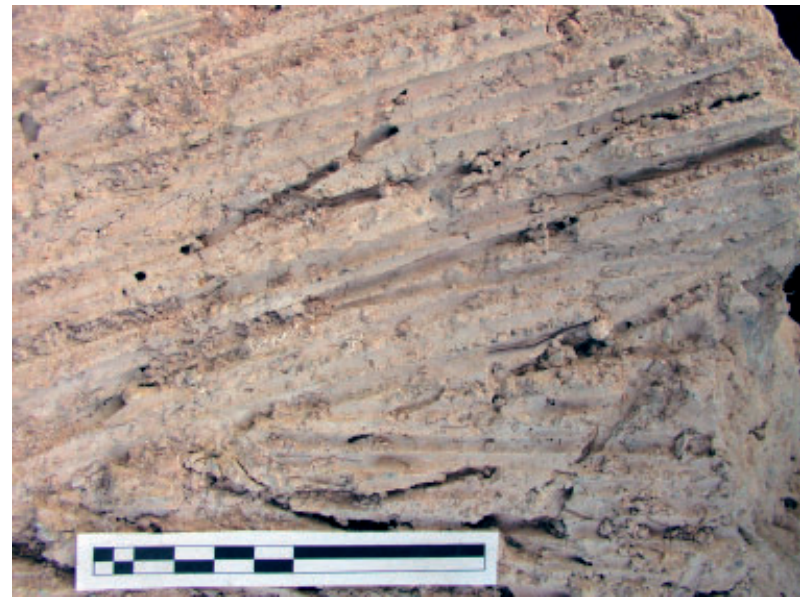

Figura 21: Impronta n. cat. 11.
N. CAT. 11 (Figs. 20 y 21). N. bolsa: 542d. N. Registro: 5307. UE 1233.

Localización: cuadrícula: J12 Estancia: IV.

Número de ejemplares: 1. Medidas: $40 \times 30 \mathrm{~cm}$.

Descripción y análisis: De la misma estancia y unidad estratigráfica pertenece la muestra n. 11 que presenta improntas de la misma factura, forma y disposición que las descritas en la muestra n. 10.

\section{N. CAT. 12 (Fig. 22). N. bolsa: 660f. N. Registro:} 3403. UE 1264.

Localización: cuadrícula: J13 Estancia: III. Derrumbe ibérico al $S$. de zapata $\mathrm{NE}$

N. ejemplares: 1 . Medidas: $5 \mathrm{~cm}$.

Descripción y análisis: Fragmento de borde de contenedor metálico, fabricado en aleación de cobre, sobre cuya cara interna se conservan, adheridos, restos que parecen corresponder con fibras vegetales carbonizadas. Aunque no es del todo evidente, parece intuirse una disposición ordenada, en entramado, de estas fibras vegetales, lo que sugeriría su pertenencia a una posible pleita (faja o tira de esparto trenzado que cosida con otras sirve para hacer esteras y otros objetos) o crisneja. A nuestro juicio, la pieza muestra una fibra sin majar.

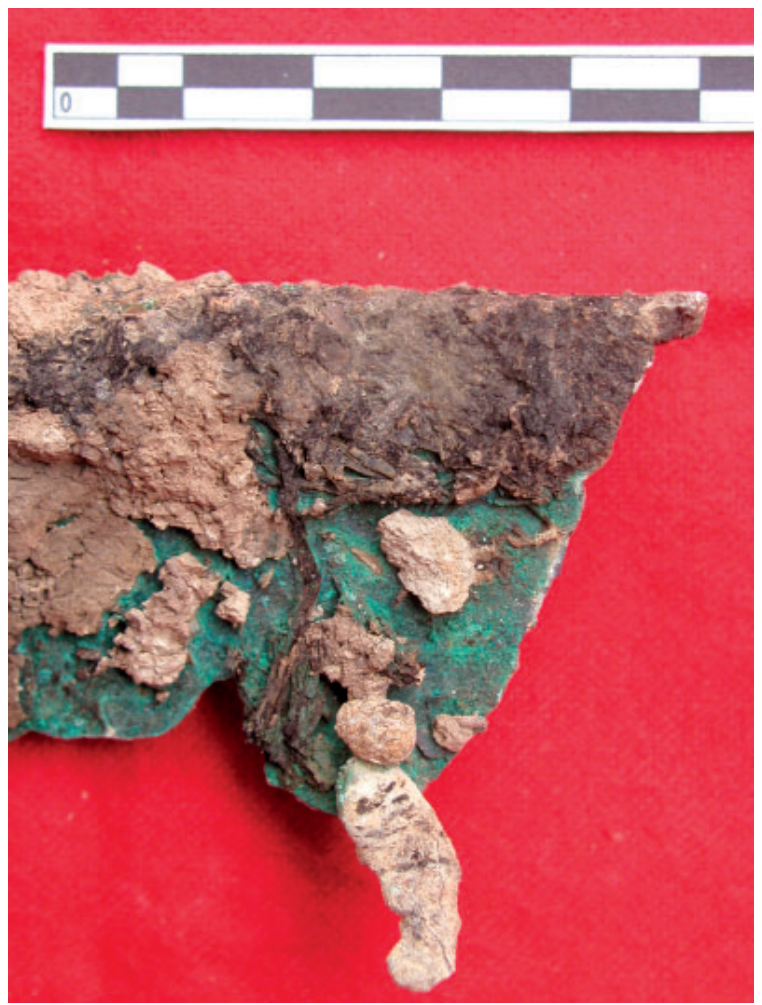

Figura 22: Impronta n. cat. 12.

N. CAT. 13 (Figs. 23-25). N. bolsa: 73. N. Registro: 2631. UE: 1004.

Localización: cuadrícula: I12-I13 Estancia: Derrumbe de adobes.

Número de ejemplares: 1.

Descripción y análisis: Presenta huellas o improntas de diámetro considerable en una de sus caras. En su 


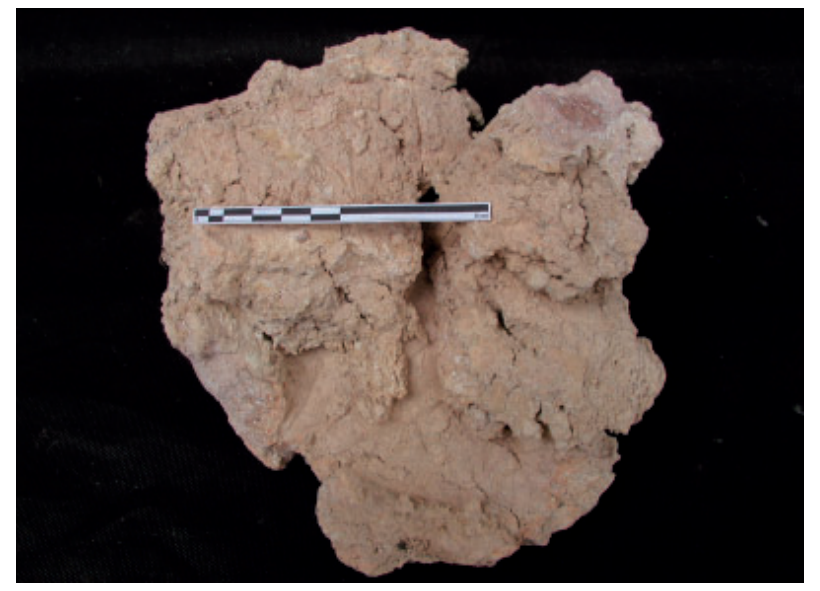

Figura 23: Impronta n. cat. 13.

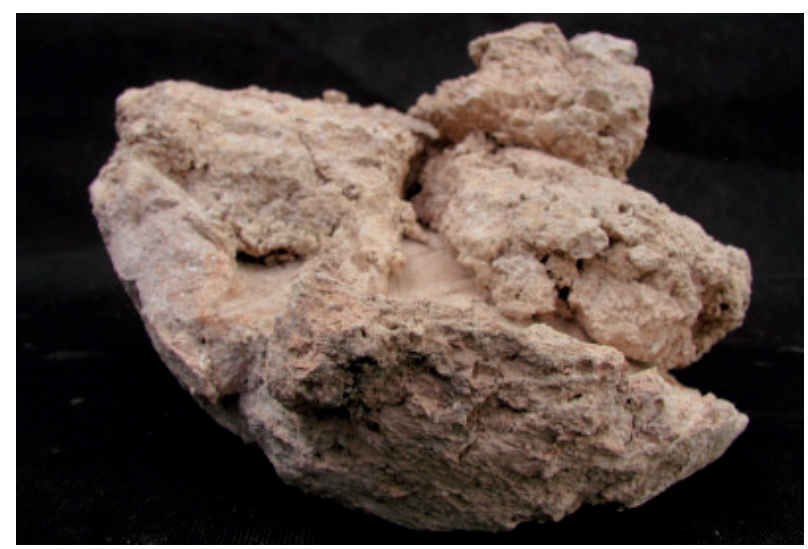

Figura 24: Impronta n. cat. 13.

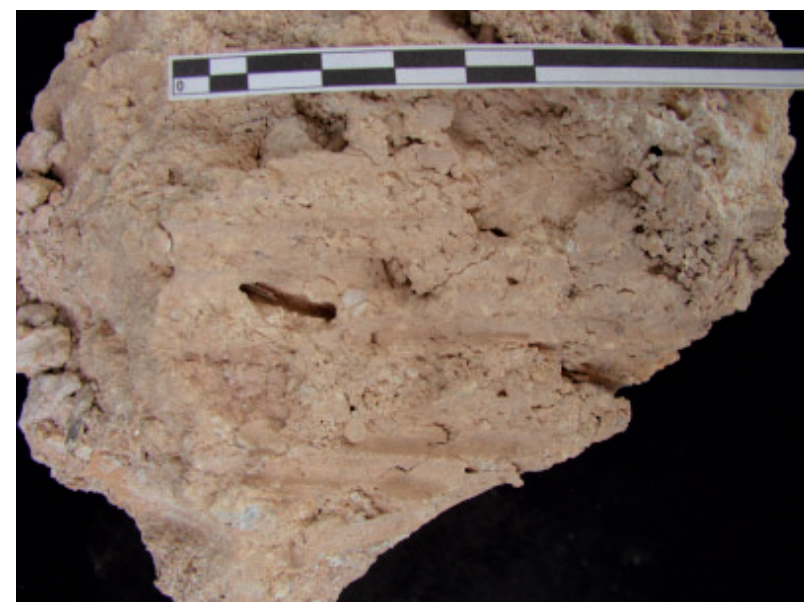

Figura 25: Impronta n. cat. 13.

cara posterior (Fig. 25) se aprecian, al menos, tres improntas de sección semicircular y considerable diámetro dispuestas paralelamente, separadas unas de otras por unos $3 \mathrm{~cm}$. A juzgar por su sección, profundidad y disposición, parecen interpretables como improntas de cañas gruesas dispuestas a cierta distancia. A juzgar por el tipo de improntas y su disposición, parece que, al menos esta parte del fragmento, formaba parte de la capa de barro colocada, mezclada con carrizo fino o paja, por encima de un entramado de rollizos o cañas gruesas dispuesto paralelamente al envigado para actuar como armazón para la cubierta vegetal. Esta solución aparece en algunas hipótesis de reconstrucción de techumbres ibéricas, como la de la Bastida de les Alcusses, que comentaremos más adelante (Bonet, Díes y Rubio, 2000, 85, fig.11). Las otras marcas son de interpretación más problemática (Figs. 23 y 24). En primer lugar la forma del fragmento es, de por sí, llamativa. Presenta una morfología muy irregular y da la impresión de que se trata de dos pellas de barro endurecido pegadas a una base, también de barro, ligeramente curva (Fig. 24). En la parte central se aprecia un surco de gran profundidad que cruza casi toda la pieza verticalmente (Fig. 23). En la parte inferior presenta, de nuevo, un surco pronunciado, de 5,6 cm de anchura y sección rectangular. Cruza horizontalmente la pieza, pero su trazado no es recto, sino curvo. Cabe destacar, asimismo, un leve vestigio de una capa de color rojo vináceo en su esquina superior izquierda. La forma de la pieza y los dos grandes surcos que presenta, uno de ellos de trazado curvo, es verdaderamente particular. No estamos en disposición de interpretar este fragmento de manera convincente. Las marcas de parte de su superficie son de cañizo y ello nos hace pensar en una capa gruesa de revestimiento de barro de la techumbre o un altillo. La forma curva de la pieza podría resultar de una capa de barro colocada en la terminación de una techumbre o primer piso, o bien, de haber estado colocada en el espacio entre dos vigas o rollizos grandes de sección redonda. Pero ni siquiera podemos asegurar que se trate de una sola pieza y no de una amalgama de pellas de barro formada durante el derrumbe y el incendio. Tan sólo podemos aventurar que, probablemente, una parte del fragmento habría sido parte del revestimiento de un encañizado o entramado de rollizos.

N. CAT. 14 (Figs. 26-28). N. bolsa: 729b. N. Registro: 5308. UE: 1341.

Localización: cuadrícula: J13-I13. Estancia: III Nivel de uso de suelo ibérico.

Número de ejemplares: 4. Medidas: 4,5X6; 8X6; $4 X 4 ; 5 X 2,5 \mathrm{~cm}$.

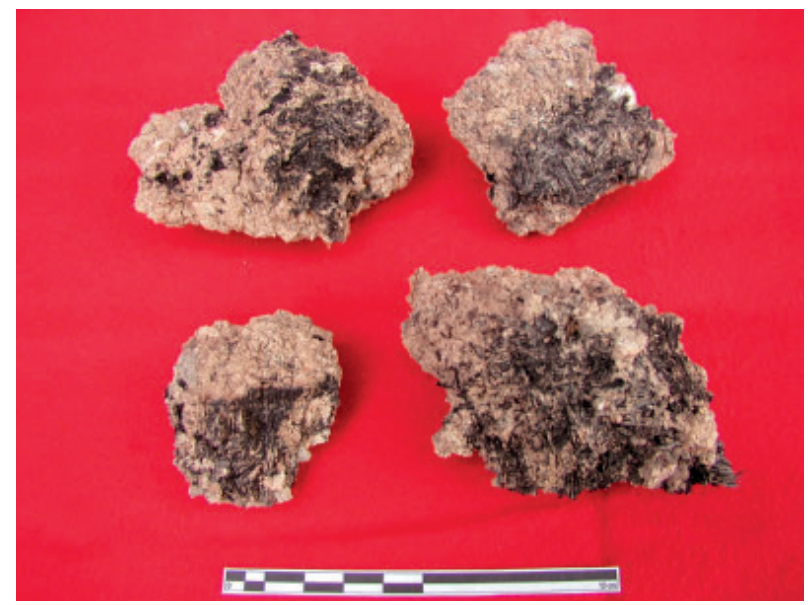

Figura 26: Muestra n. cat. 14. 


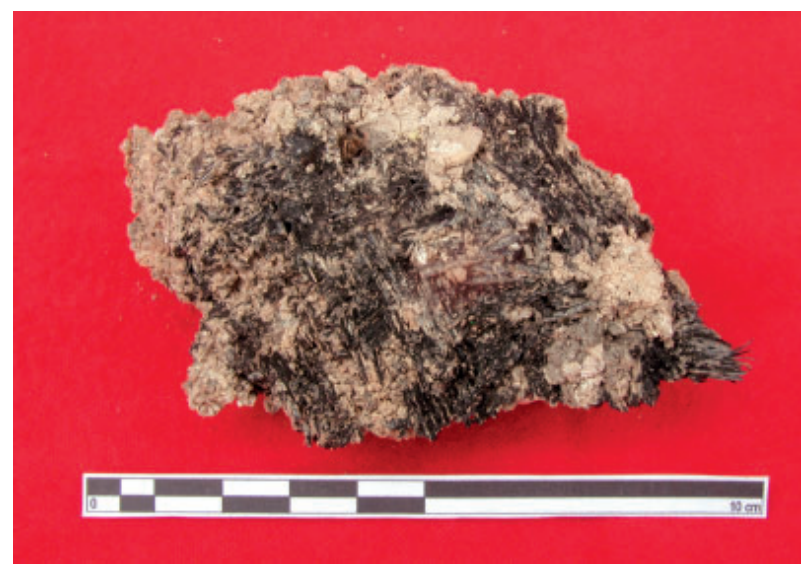

Figura 27: Muestra n. cat. 14.
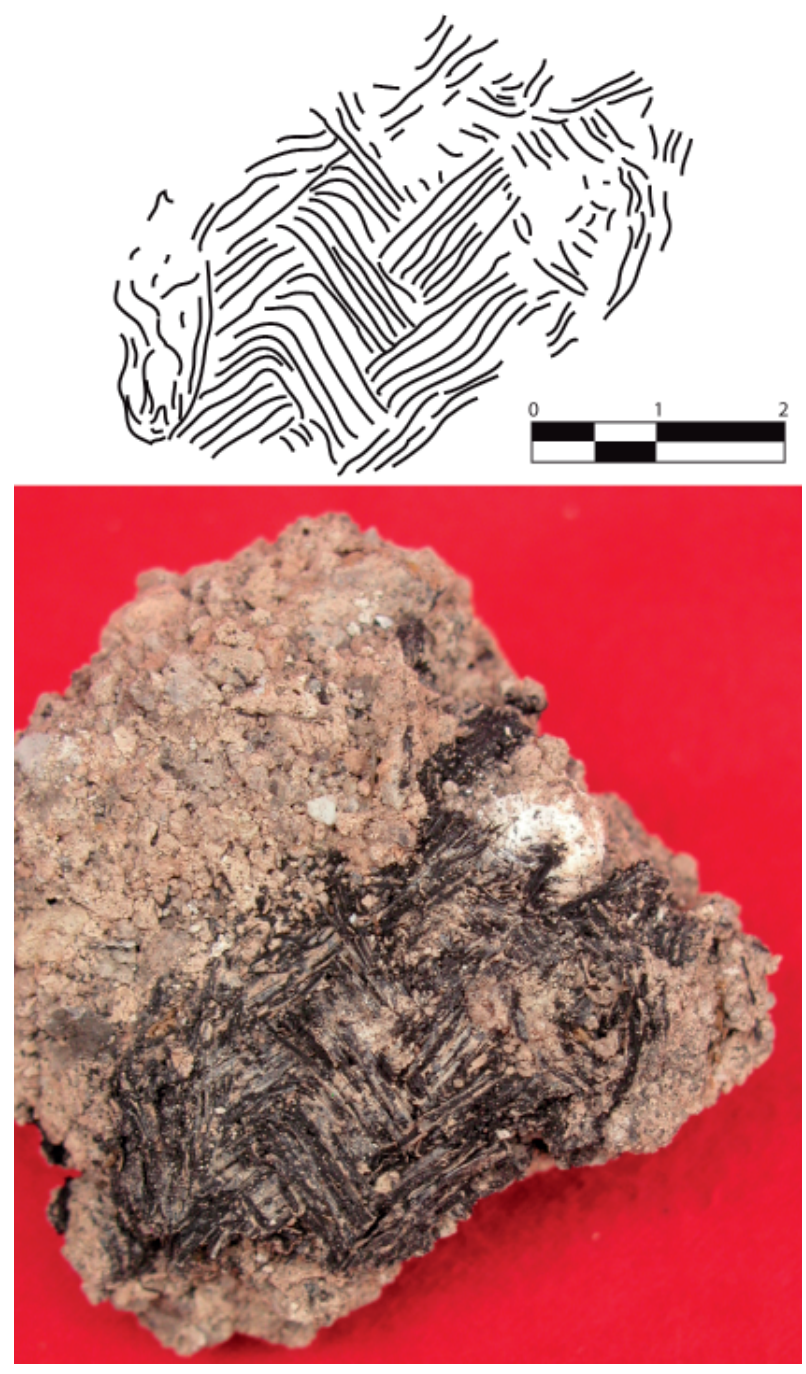

Figura 28: Muestra n. cat. 14.

Descripción y análisis: Cuatro fragmentos de pleita de fibras carbonizadas, casi con toda seguridad de fibras de esparto. Su entramado es en sargas de $2 \times 2$. Uno de los fragmentos muestra lo que parece ser el borde de la pleita. La similitud de las cuatro muestras, así como su cercanía física, hacen muy probable su pertenencia a un mismo objeto.

\section{DISCUSIÓN}

Todas las huellas o improntas vegetales estudiadas nos han dejado una suerte de «radiografía» del tipo y forma de los elementos vegetales que allí quedaron impresos. Gracias a los estudios palinológicos y antracológicos realizados en el Cerro de la Cruz, sabemos que en el entorno del río Almedinilla, adyacente al asentamiento ibérico, existía a fines de la II Edad del Hierro una abundante vegetación de ribera que hemos detallado antes. Las muestras que hemos estudiado pertenecen todas ellas a un tipo de vegetación esencialmente característica de la flora de ribera de la región en que se halla el Cerro. Se trata de un tipo de cañas de diverso grosor, que emplearon los constructores ibéricos como material, siempre asociados a la tierra, el agua y la paja, para edificar las techumbres del poblado. Es bien conocida la importancia de la paja en el proceso de fabricación y consolidación de los módulos de adobe empleados para levantar el alzado de los muros en el mundo ibérico. Ahora bien, para fabricar las techumbres se empleaban básicamente elementos vegetales, sobre los que se colocaban una o dos gruesas capas de barro que, a veces, se encalaban, a fin de que adquiriesen consistencia; todo ello reposaba sobre una estructura lígnea a base de vigas de madera y, en ocasiones, rollizos de cañas. La combinación de cañas y barro, cubría los vanos de la estructura de madera y constituía una cubierta ligera que impedía la entrada del sol y la lluvia en el interior del edificio y podía ser reparada o sustituida con relativa facilidad. Los pobladores del Cerro de la Cruz optaron por elaborar este tipo de cubiertas con tallos de cañas silvestres y de carrizo idénticos a los que hoy mismo podemos encontrar en la ribera del río Saladillo a escasos km del poblado ibérico.

El plano de hallazgos de muestras con improntas (Fig. 4) muestra una distribución espacial muy definida de aquellas que, por sus trazas de vegetales, parecen corresponder a vestigios de elementos constructivos, bien de los adobes destinados a los muros, bien de los elementos de tejados y plantas altas. De las 11 muestras sometidas a estudio, 8 se hallaron en contextos de habitación (Fig. 29). No sólo esto sino que aparecieron, por lo general, en niveles estratigráficos asociados a derrumbes de material edilicio de las casas y almacenes del poblado. Es más, exceptuando, los nos. 4 y 5 , que parecen más bien restos de adobes paramentales, el resto de las piezas del muestreo son identificables como vestigios de pisos y cubiertas. En este sentido, los propios contextos nos proporcionan un elemento de análisis más que, sumado al estudio de las marcas, aportan una solución satisfactoria al origen y naturaleza de las marcas vegetales impresas en los vestigios del yacimiento.

Partimos de que las improntas aparecen en el momento en el que el barro (ya fuesen adobes u otros elementos de recubrimiento) estaba húmedo, por tanto en el momento de construcción de las estructuras. En 


\begin{tabular}{|l|l|l|l|l|}
\hline UE & $\begin{array}{c}\text { Contexto } \\
\text { habitación }\end{array}$ & $\begin{array}{c}\text { Número (cantidad) de } \\
\text { piezas (individuos) con } \\
\text { improntas }\end{array}$ & $\begin{array}{c}\text { Números de } \\
\text { catálogo }\end{array}$ & Descripción de la Unidad estratigráfica \\
\hline 1001 & Sí & 2 & $8-9$ & «Superficie» \\
\hline 1004 & Parcial & 5 & $3,4,5,13$ & «Derrumbe de adobes» \\
\hline 1014 & Planta alta & 1 & 1 & «Derrumbe adobes y suelo con restos humanos» \\
\hline 1111 & Sí & 1 & 6 & «Tierra gris bajo UE 1106» \\
\hline 1156 & Sí & 1 & 7 & «Derrumbe norte de la estancia V» \\
\hline 1233 & Sí & 2 & $10-11$ & $\begin{array}{l}\text { «Derrumbe «amarillento» al sur de la unidad } \\
\text { constructiva 1237» }\end{array}$ \\
\hline
\end{tabular}

Figura 29: Tabla de contextos de habitación.

el caso de los adobes para muros, es bien conocido el proceso de fabricación y secado de las piezas: se mezclaba tierra y agua, y se le añadía desgrasante (normalmente paja), la pella se amasaba inicialmente con las manos y posteriormente se modelaba, inicialmente con las propias manos, y después empleando un pequeño molde de madera (no una estructura de encofrado) en el que se introducía la mezcla para darle su forma definitiva. Una vez extraída la pieza del molde (sobre sus módulos ver Vaquerizo, Quesada y Murillo, 2001, 102-103), se dejaba a secar al sol para que adquiriese la consistencia necesaria. Belarte apunta la necesidad de distinguir convenientemente entre las técnicas de encofrado y modelado; señala que a menudo se clasifican como «muros de tapial» paramentos de adobe relativamente estrechos y de trazado no rectilíneo que realmente han sido elaborados a base de adobes modulados (Belarte, 2001, 34; también De Chazelles, 1999, 229-254).

Dicho esto, las trazas de paja que hallamos, claramente impresas, en los ejemplares n. 4 y n. 5 de nuestro catálogo (Figs. 10 y 11) parecen más bien interpretables como restos de paja que se fueron quedando adheridos a la superficie de las piezas mientras estas se secaban al sol. Así parece constatarlo el tipo de impronta, el hecho de que la pieza se conserve en casi todo su tamaño original, y que sólo aparezcan trazas en una cara y con un lecho muy leve.

El caso de los ejemplares con improntas de sección semicircular o circular (o bien rectangular) y disposición en paralelo, o entramado, es bien distinto. La técnica de construcción de los tejados de las casas ibéricas es conocida, o al menos intuida con un criterio razonablemente científico, y se mantuvo invariable en sus aspectos básicos, durante toda la segunda Edad del Hierro; de ella hablaremos más adelante. Lo que aquí conviene destacar es que, en la fabricación de las techumbres, semipisos, o primeros pisos de las casas, se aplicaba una gruesa capa de barro por encima de la estructura de vigas de madera y del enramado fabricado a base de cañizo. Dicha capa debía tener grosor suficiente para reforzar toda la estructura y sustentar, tanto el piso, como la techumbre (Bonet, Díes y Rubio, 2000, 85, fig. 12). Ahora bien, el barro se aplicaba aún fresco sobre las vigas de madera y el cañizo, de aquí que adquiriera parcialmente la forma de las cañas así como el de las propias vigas.

Con la destrucción del poblado, techos y muros se vinieron abajo, formando un gran paquete de derrumbe que se compactó y endureció por acción química y quizá el calor del incendio. Contamos, por tanto, con tres tipos de evidencias básicas: (a) fragmentos de la capa de barro que se aplicaba encima del entramado vegetal de cañizo en las techumbres, (b) restos del encañizado con barro de los semipisos y (c) adobes destinados a los muros que conservan adherencias de elementos vegetales, aunque, como veremos, los dos primeros tipos apenas se pueden diferenciar en el Cerro de la Cruz. A ello hay que añadir evidencias de mechinales en muros de adobe, huecos paralelos de sección semicircular, que ya hemos discutido en otro lugar (Vaquerizo, Quesada y Murillo, 2001, fig. 37n, 103 ss.). En los fragmentos de adobe que conservamos, las improntas aparecen sólo en una de sus caras. En cuanto a las demás, la naturaleza y disposición de las trazas nos lleva a concluir que la mayor parte son restos de la cara interna de la capa de barro de la que hemos venido hablando. No obstante, es preciso tener en cuenta que, en muchas ocasiones, la impronta de carrizo no tiene por qué quedar sólo en la superficie del fragmento de barro recuperado, pues, al adoptar la forma de los rollizos de madera, el barro fresco se mete entre las juntas y espacios del envigado $\mathrm{y}$, debido a su grosor, y a la aplicación de sucesivas lechadas, quedan a menudo cañizos dentro de la propia capa de barro. De resultas de esto, la impronta aparece, a veces, en medio de la pella endurecida de barro que recuperamos en contexto de excavación; tal es el caso del ejemplar número 8 del catálogo que presentamos, y más claramente de los recuperados en el yacimiento ibérico del Barranc de Gàfols, que trataremos en el apartado de paralelos (Fig. 30).

Conviene en todo caso señalar la dificultad para precisar las diferencias entre las improntas originadas por la presencia de cañas comunes y aquellas que pertenecen a tallos de carrizo (supra para la distinción posible). En principio, el criterio distintivo habríamos de buscarlo en los diámetros de los propios surcos que dejan los tallos en el barro. En la mayoría de los casos la impronta es de sección semicircular, al haber quedado impresa la huella sólo por uno de los lados de la 


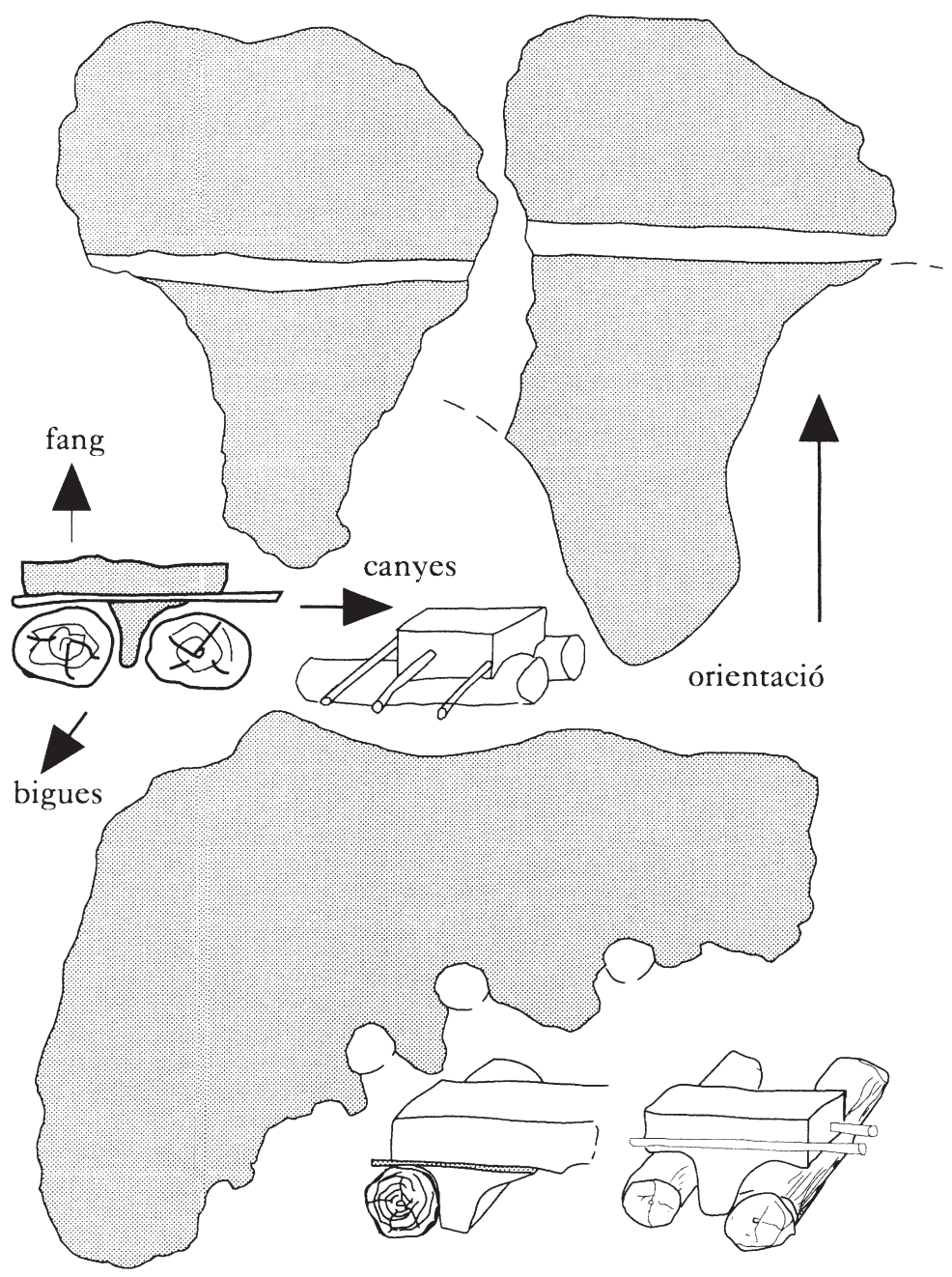

Figura 30: Sección de diversos fragmentos de barro procedentes de las cubiertas derrumbadas del Barranc de Gàfols. Según Morer et alii, 2001, 162, fig. 8 .

pella de barro, lo que dificulta la medición. Aun así, podríamos aventurar que las huellas de las muestras n. 3 (Fig. 9), parte de las de la n.9 (Fig. 15), la mayoría de las de la n.10 (Figs. 16-19), y, finalmente, las de la n. 11 (Figs. 20 y 21) pertenecen probablemente a tallos de carrizo con diámetros considerablemente bajos que oscilan entre 1 y $1,5 \mathrm{~cm}$. También así parece indicarlo la tendencia a la disposición paralela de los surcos, entre sí, pero en muchas ocasiones en posición diagonal respecto a la superficie de adobe, a la manera de un entramado que se entrecruza con otras estructuras. Por otra parte, algunos los surcos de la muestra n.8 (Fig. 14) conservan diámetro completo, de unos $2,7 \mathrm{~cm}$, considerablemente mayor que el de la mayoría de trazas; estas últimas trazas, junto con algunas de la muestra n. 10, que además están dispuestas en posición ligeramente perpendicular a las otras marcas, podrían corresponder a cañas más gruesas. No obstante, insistimos en la dificultad de precisar hasta este nivel de detalle, debido al número de muestras y su estado de conservación, que proporcionan una evidencia notable pero de análisis complicado.

\section{UNA ARQUITECTURA DE 'MATERIALES MENORES'}

Es bien sabido que las construcciones formadas con lo que podemos llamar «materiales menores» como el barro, la tierra, la madera y diversos elementos vegetales, no han recibido la misma atención en el seno de la investigación arqueológica tradicional que las grandes obras en materiales duros. Sobre este hecho llamaron la atención hace ya unos años $\mathrm{P}$. Arcelin y $\mathrm{O}$. Buchenschutz en un notable trabajo conceptual sobre la arquitectura protohistórica (Arcelin y Buschenschutz, 1985, 15). Según estos dos autores, la causa de ello reside en el concepto que hemos heredado del propio Vitrubio de considerar que la arquitectura propia de la «civilización»es aquella que se realiza con materiales duros y «nobles». Afortunadamente, en los últimos decenios el panorama ha cambiado: los trabajos de excavación y los consecuentes análisis arquitectónicos de los yacimientos protohistóricos exhumados, han despertado una sensibilidad en la investigación europea por la construcción que podríamos resumir como «de 
barro y madera». Trabajos como el ya citado de Arcelin y Buchenschutz, fueron pioneros de una ya larga lista de contribuciones que han arrojado luz sobre la cuestión (entre los más destacados: Buschsenschutz, 1984; Buchsenschutz y Mordant, 2005; Pinigre y Nicolas, 2002).

En el caso de la península ibérica, y, concretamente en el ámbito ibérico de la II Edad del Hierro, el incremento de los estudios sobre arquitectura doméstica ha sido exponencial en los últimos veinte años, y ha avanzado paralelamente a los de la excavación. Es preciso destacar que no sólo han ido apareciendo tratamientos teóricos sobre las técnicas constructivas ibéricas, sino que, se han realizado, sobre todo en Cataluña, diversos proyectos de reconstrucción de ámbitos domésticos ibéricos que han resultado de gran utilidad para comprender mejor los fundamentos y problemas de la arquitectura de esta cultura (Abad, 1996, 123-145; Abad y Sala, 1993; Abad y Sala, 2001; Belarte, 1999-2000, 65-93; Belarte, 2001, 27-41; Belarte, Sanmartí y Santacana, 1994, 231-243; Belarte, Noguera y Sanmartí, 2002, 89-110; Belarte, Bonet y Sala, 2009, 93-123; Belarte, 2010; Bonet y Guerin, 1995, 85-104; Pou, Sanmartí y Santacana, 1995, 51-62; Sánchez, 1999, 161-188; Guerin, 2003, entre otros). Es, en este sentido, destacable el trabajo que desde 1995 se ha venido haciendo en el yacimiento ibérico catalán de L'Alorda Park o Les Toixoneres, cuyos responsables han sido pioneros en las actividades de reconstrucción basada en patrones documentados científicamente (Pou, Sanmartí y Santacana, 1995).

No obstante, en la cuestión que a nosotros nos atañe aquí (las techumbres y coberturas de las casas ibéricas), sigue existiendo un notable vacío de información debido a que los tejados se construían con materiales perecederos que no se suelen conservar en los yacimientos y, por tanto, nuestra información en el registro arqueológico se ve, por lo general, muy limitada. Aun así, algunos trabajos en yacimientos ibéricos catalanes y levantinos, junto con otros paralelos, no necesariamente ibéricos o de la Edad del Hierro, en el resto de Europa, nos pueden ilustrar a la hora de reconstruir la forma de elaborar las techumbres en la arquitectura doméstica ibérica. De hecho, los testimonios que presentamos aquí constituyen un conjunto único y novedoso por la cantidad de improntas conservadas, la relativa claridad del tipo de vegetación a la que corresponden, los contextos de hallazgo dentro de la excavación, y el estado de conservación de las mismas.

Si bien por medio del análisis de la arquitectura tradicional, mediante la etnografía comparada y la etnoarqueología, podemos extraer datos interesantes, y a menudo concluyentes, como ha ocurrido en el caso del Cerro de la Cruz (Quesada, Kavanagh y Moralejo, 2010, 75-95), muchas veces las necesidades, el clima y los recursos son diferentes en períodos y áreas diversos, lo que convierte las arquitecturas y sus respectivas evoluciones en algo muy diverso también.
Por lo que respecta a las fuentes literarias grecolatinas, desde un punto de vista general, no muestran interés por la arquitectura doméstica de los pueblos bárbaros, si exceptuamos algún comentario aislado. El propio Vitrubio casi excluye los materiales perecederos del concepto de arquitectura. En el caso de la península ibérica, y más concretamente de las cubiertas, contamos con algunos pasajes dignos de mención como los de Tito Livio y Dion Casio, que nos hablan de la destrucción inmediata de los tejados de las casas de los poblados ibéricos de Iliturgis y Ategua al quemarse merced a los dardos incendiarios enemigos (Liv. XXVIII 19-20; Dion. Cas. XLIII 34, 3). Este dato parece confirmarnos la composición en materiales vegetales de las techumbres, pero las capas de barro que hubieran dificultado tales incendios no se tienen en cuenta.

\section{CUBIERTAS VEGETALES DEL CERRO DE LA CRUZ EN EL CONTEXTO IBÉRICO PRERROMANO}

Durante todo el período ibérico, o al menos desde finales del siglo VI hasta el siglo II a. C, aproximadamente, se puede constatar una relativa uniformidad en los elementos y técnicas constructivas del área geográfica que ocupaba la cultura ibérica: podemos hablar, pues, de la tierra o barro, la piedra y diversos elementos vegetales, como materiales básicos, si bien un estudio detallado arroja diferencias técnicas de diversa índole a la hora de combinar estos materiales. Las características básicas de la «casa» íbera aparecen bien documentadas sobre todo en la zona costera septentrional del ámbito ibérico (en yacimientos como Ullastret, La Penya del Moro o Puig de la Nau, entre otros) ya desde fines del siglo VI a. C, parece que, en conexión con la arquitectura desarrollada en el sur de la Galia desde tiempos del Bronce Final, así como con el contacto con los colonos griegos establecidos en Ampurias desde el 580 a. C. (Belarte, 2001, 27; García, 2000, 70; Francès y Pons, 1998, 31-46).

En la zona meridional del territorio ibérico, ámbito que nos toca más de cerca, parece que las estructuras de habitación propias del sustrato tartésico, construidas íntegramente en materiales perecederos, sufren modificaciones sustanciales a partir de mediados del siglo VIII a.C., cuando se introduce el adobe por medio del contacto con el mundo fenicio (Pellicer y Schüle, 1962, 6). De esta forma, y progresivamente, se iría configurando en todo el ámbito ibérico, un modelo arquitectónico que podríamos describir como semi-perecedero por el carácter mixto de sus elementos constructivos. Por una parte, elementos duraderos: los zócalos, que se elaborarán en piedra, y los muros, que progresivamente y mediante diversas influencias en el área septentrional, levantina y meridional, se acabarán construyendo casi en su totalidad de adobe; por otra parte, las puertas ventanas y cubiertas seguirán construyéndose, en esencia, con madera y caña. 
No es lugar este para el análisis detallado del espacio doméstico ibérico y todos sus componentes y evolución (ver al respecto Guerin, 2003, 280-290, con bibliografía). Nos centraremos, pues, en las soluciones arquitectónicas con elementos vegetales para las techumbres. La práctica totalidad de elementos de impronta conservados sobre soportes de barro endurecido procedentes de cubiertas vegetales han aparecido en yacimientos ibéricos del área catalana y levantina en una horquilla cronológica amplia entre principios del Ibérico Antiguo y fines del Ibérico Pleno. Sobre todo, se han podido conservar restos de los tejados en los yacimientos que han sufrido incendios, puesto que suelen aparecer bajo los niveles de derrumbe de los muros, y sobre el pavimento, en forma de estrato de cenizas procedente de la combustión de la cubierta vegetal, como ocurre en el propio Cerro de la Cruz (Quesada, Kavanagh y Moralejo, 2010, 75-95 y Belarte, 1997, 72, con bibliografía). Contamos con paralelos directos para nuestras improntas en los yacimiento de: Puig Roig (Tarragona), Barranc de Gàfols (Tarragona), L'Alorda Park (Calafell, Tarragona), el Castellet de Bernabé (Liria, Valencia) o Les Escodines Altes (Maçalió, Tarragona).

En orden cronológico, comenzaremos por el poblado de Puig Roig (Priorat, Tarragona). Se trata de un enclave con fase de ocupación datada entre los siglos X y VI a.C. perteneciente al horizonte cultural de Campos de Urnas. A pesar de no ser un yacimiento propiamente ibérico, conserva importantes trazas de construcción de cubiertas con materiales vegetales; las técnicas documentadas en este yacimiento tendrán continuidad, casi inalterada, en el mundo ibérico del área catalana desde principios del siglo VI a. C. en adelante. En diversas estancias se recuperaron fragmentos de barro con numerosas improntas vegetales (Genera, 1995, 34, figs. 23, 24). El tipo de improntas, dispuestas, bien en paralelo, bien ligeramente en diagonal, a la manera de un entramado, muestran la utilización de cañizos dispuestos paralelamente, y de manojos de cañizo fino colocados por encima y entre las vigas. Las improntas de la habitación I de este yacimiento muestran, además, que encima de la primera capa de barro endurecido que estaba en contacto con el encañizado se colocaban otras capas, más o menos gruesas con abundantes elementos vegetales (Belarte, 1997, 73). En este sentido, hemos de destacar las muestras n. 3, 9 y 10 de nuestro catálogo corresponderían con estas técnicas.

El Barranc de Gàfols es un pequeño yacimiento de no más de 300 metros cuadrados, en el que se ha documentado un asentamiento con fase de poblamiento ibérico no anterior a los años 590/580 a.C. Según los excavadores, la ausencia de cerámica griega de importación y de otros materiales que proporcionen cronologías precisas dificulta la datación de la fase de ocupación ibérica del yacimiento. El terminus ante quem de dicha fase de ocupación, vendría dado por la ausencia de cerámicas de tipo ibérico antiguo (Belarte et alii,
1993, 63-72; Belarte, Sanmartí y Santacana, 1994, 231-243). En el proceso excavación de las diversas estructuras arquitectónicas exhumadas, se documentaron capas de ceniza de entre 5 y $20 \mathrm{~cm}$ de espesor, de la combustión y desintegración de compuestos de las cubiertas y otros elementos lígneos de las estancias (Belarte, 1997, 72). Son significativas para nosotros tres muestras de barro con improntas; las dos primeras, conservan improntas de sección semicircular y diámetro amplio de rollizos de madera del envigado del tejado (Belarte, 1997, 72, figs. 54 y 55).

No tenemos en el Cerro de la Cruz ninguna pieza con trazas directas de rollizo de sección circular, lo que nos lleva a plantear la posible construcción de estos con vigas de sección semicircular (evidenciadas por los mechinales ya citados) y cuadrada. Son reseñables en este sentido los ejemplares n. 6 y 7 de nuestro catálogo, que parecen conservar improntas de sección cuadrangular que podrían pertenecer a un sistema de soporte de las techumbres a base de vigas y elementos secundarios como partes de una trama secundaria de maderos (dada la reducida sección de estas improntas), aunque no podemos asumirlo con certeza en ninguno de los dos casos. La tercera muestra sí entra en relación directa con los ejemplares del Cerro de la Cruz. Se trata de un fragmento aparecido en los niveles de derrumbe de la habitación $\mathrm{n}$. IV, con diversas marcas de encañizado y de dos pequeños troncos dispuestos perpendicularmente a las cañas y separados por unos $2 \mathrm{~cm}$ (Belarte, 1997, 73-74). Una de las superficies es plana y la otra presenta improntas, exactamente igual que la mayoría de ejemplares del catálogo aquí presentado. Otro fragmento de la estancia I del mismo yacimiento, presenta claras huellas de sección semicircular, muy profundas que pertenecen, sin duda, a cañizo (Belarte, 1997, 109, fig. 89). La profundidad de las trazas, la alta depuración del barro y el escaso número de huellas, así como su disposición, totalmente paralela y regular, ha hecho pensar a algunos investigadores en la posibilidad de que existiesen encañizados dispuestos verticalmente y revestidos de arcilla destinados a los vanos (Belarte, 1997, 109). De nuevo las piezas n. 3, 8, 9, 10, 11 y 13 de nuestro catálogo hallarían paralelos con estos ejemplares, exceptuando la última muestra descrita.

El asentamiento ibérico edetano del Castellet de Bernabé (Liria, Valencia), presenta una fase de ocupación datada entre los siglos V y III a. C. Cuenta con unos unos mil metros cuadrados de extensión y destaca por la excelente conservación de sus estructuras arquitectónicas, que lo han convertido en uno de los mejores exponentes para el estudio de la arquitectura ibérica (Guerin, 2003). Sin embargo, según testimonio de los propios excavadores, el estudio de los distintos tipos de cubiertas cuyos restos se han conservado en los derrumbes, presenta el hándicap del estado sumamente fragmentario de la propia evidencia. Cabe destacar un fragmento de mortero de tierra de unos $20 \mathrm{~cm}$ cuadrados, procedente del departamento $\mathrm{V}$, con impronta de una pieza de madera y dos clavos de hierro clavados y 


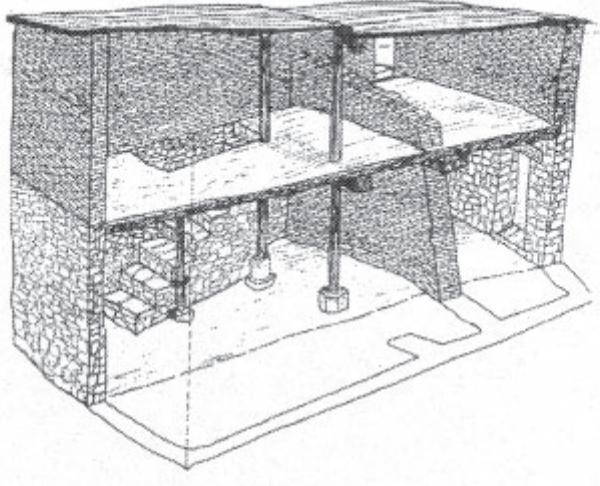

a
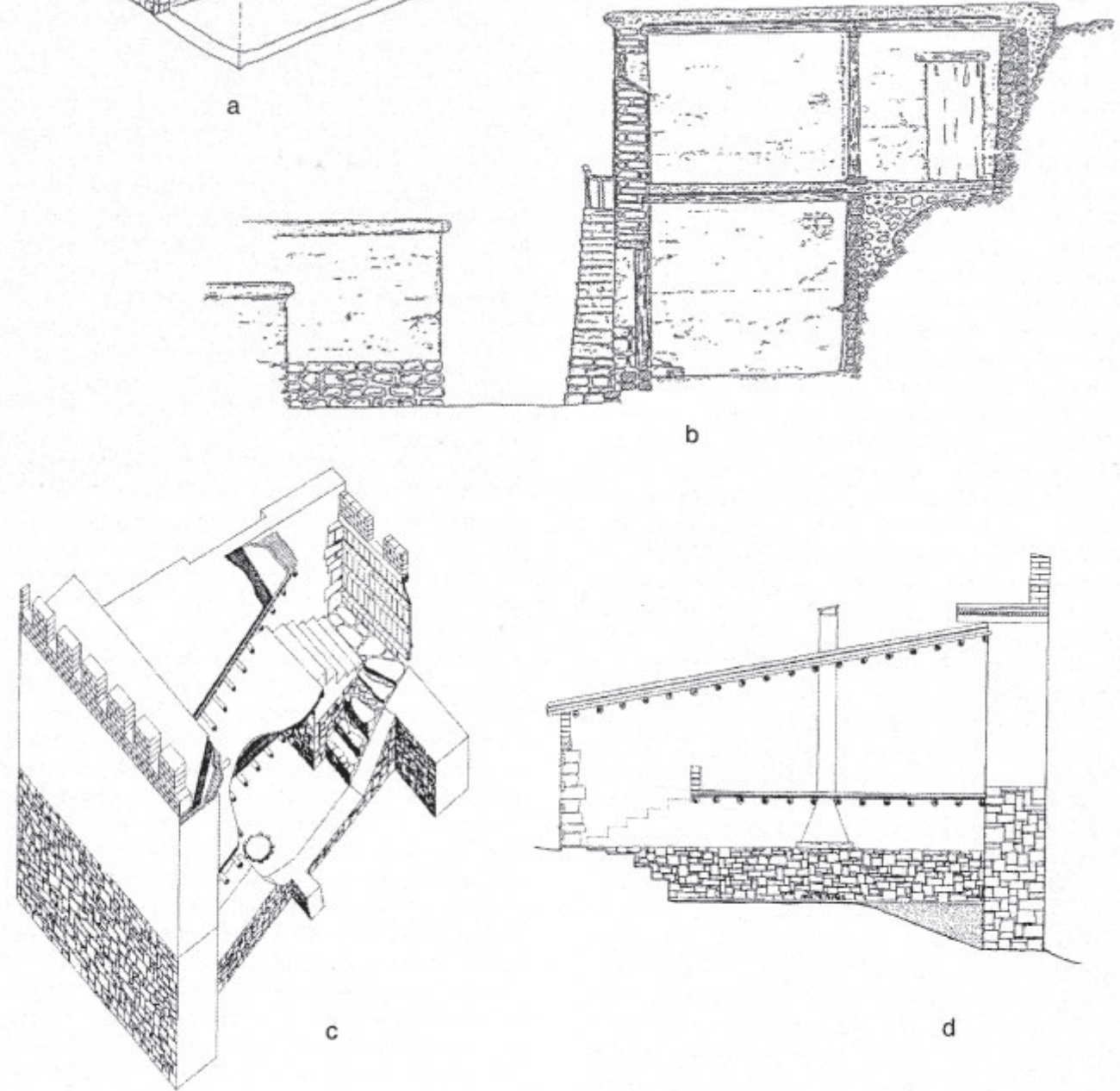

d

Figura 31: Propuestas de reconstrucción con un piso superior hechas en diferentes poblados ibéricos. Según Belarte, 2001, 38, fig. 19, a partir de diversos autores. A.-Puig de la Nau; B.-San Miguel de Lliria; C.y D. La Moleta del Remei.

cruzados (Guerin, 2003, 230, fig. 284). Se trata de un fragmento de techumbre con una viga que se carbonizó en el incendio del poblado, en el último tercio del siglo III a.C. Este fragmento prueba, de nuevo, el empleo de tierra para cubrir los vanos de la estructura de vigas de madera. Los trabajos arqueológicos en los niveles de derrumbe del poblado han revelado la existencia de dos tipos básicos de muestras de cubiertas vegetales: un primer grupo de fragmentos de barro endurecido con una cara lisa y la otra con improntas de sección semicircular no inferior a $5 \mathrm{~cm}$ y dispuestas en paralelo o formando entramados. Estas presentan una capa de tierra de entre 10 y $15 \mathrm{~cm}$ de grosor y parecen pertenecer a rollizos de madera circulares o caños muy gruesos
(Guerin, 2003, 230). El segundo grupo, está constituido por fragmentos que no portan improntas de madera, sino de tallos dispuestos en manojos, según los excavadores, los tallos son de romero (Guerin, 2003, 230). Este segundo grupo es claramente asimilable a los números 3, 8, 9, 10 y 11 de nuestro catálogo, con la única excepción de que en el Cerro de la Cruz, parece que se trata de cañizo de tronco grueso y carrizo, más fino. Según los excavadores, estos dos grupos de improntas en fragmentos de barro endurecido son hallazgos habituales en casi todos los derrumbes del poblado, aunque señalan la dificultad de identificar las improntas de ro1lizos o vigas de madera debido a su diámetro, cuando el barro se halla desmigajado (Guerin, 2003, 230). 
En los almacenes del Museo Arqueológico de Barcelona se conserva un fragmento de adobe procedente del yacimiento de Les Escodines Altes (Maçalió) con claras improntas de madera (Belarte, 2001, 35, fig. 15). Las huellas visibles se pueden atribuir a las vigas de madera, otras, menos perceptibles, a cañas. Por la disposición y anchura del surco de la impronta esta pieza recuerda a la n. 13 del catálogo que presentamos aquí (Figs. 23-25), y, sobre todo, a las improntas de la n. 7 (Fig. 13). El aspecto de las huellas, de surco considerablemente ancho y sección rectangular, así como su disposición paralela, nos hacen pensar en trazas de vigas de madera que quedaron impresas en estos adobes. La muestra de Les Escodines Altes nos ayuda en este caso a aventurar que, seguramente, estemos ante un fragmento del barro de la cubierta, o bien de un segundo piso, en el que han quedado impresas las vigas de madera. Este fragmento es, además, especialmente significativo porque conserva, también, dos claras improntas de cañizo de sección semicircular que atraviesan la parte inferior de la pieza a lo ancho. Las trazas verticales y paralelas de las vigas de madera, junto con las horizontales, de las cañas, demuestran la colocación de encañizados en sentido contrario a la disposición del envigado de madera, y por encima de este, para cubrir los espacios vacíos del armazón.

En lo que respecta a las cubiertas ibéricas, podemos hablar de una continuidad en su técnica constructiva y los materiales con respecto a la Primera Edad del Hierro. El esquema básico es el de la colocación de un envigado de madera sobre el que se apoyará una trama de elementos vegetales que lo cubra y, finalmente, se disponían una o dos capas gruesas de barro mezclado con agua y desgrasantes vegetales. Este sistema de construcción de cubiertas se mantendrá durante todo el período ibérico hasta época romana altoimperial o muy tardíamente republicana, cuando se empiecen a documentar tejas en algunos yacimientos. Un aspecto a tener en cuenta para el estudio de las cubiertas es la existencia frecuente de semipisos y primeras plantas en las estructuras de habitación. El hallazgo de muros de gran grosor y altura, los restos de techumbre orgánica y de material cerámico caídos desde lo alto, o de pilares centrales que funcionan como elemento sustentante, corroboran esta hipótesis. Existieron pues estos semipisos en las casas de yacimientos de Sant Miquel de Lliria, Calafell (L'Alorda Park), la Penya del Moro, la Moleta del Remei, el Castellet de Bernabé, y el propio Cerro de la Cruz, entre otros enclaves (Belarte, 2010, 35-37). En las excavaciones del Cerro de la Cruz se ha podido comprobar que los niveles estratigráficos excavados en el contexto de las unidades de habitación, no sólo corresponden al derrumbe de las paredes y la cubierta, sino también a estos semipisos. El hecho de que la alzada de los muros alcance cierta altura, que tengamos improntas sobre niveles de derrumbe y no directamente de uso, o restos de cerámica de almacenaje fragmentados y en el suelo en esos mismos niveles, así lo atestiguan. En el caso del cerro de la Cruz, se ha podido documentar una estancia de planta trapezoidal en la que las ánforas caídas desde la alacena o semipiso de arriba, han quedado intactas en el suelo del nivel de uso de la planta baja, en posición invertida. (Quesada, Kavanagh y Moralejo, 2010, fig. 41). El semipiso podía funcionar, entre otros usos, como un espacio de almacenaje y se construía normalmente del mismo modo que la cubierta; con madera, vegetales y barro (Fig. 31).

Como hemos podido comprobar, el análisis de las improntas sobre barro nos lleva a constatar una técnica común, con diversas variantes, a todo el ámbito ibérico. Ahora bien, en yacimientos como el Castellet de Bernabé o el Barranc de Gàfols, existen distintos tipos de fragmentos con improntas que no sólo se diferencian en su tamaño, forma y profundidad, sino también en su deposición y en los materiales con los que se encuentran asociados. Los investigadores del Castellet de Bernabé, plantean una serie de hipótesis concernientes a distintos tipos de cubiertas vegetales y pisos, que se deben considerar. Según su criterio: "de acuerdo con sus diferencias y propiedades, distintos papeles deberían ser asignados a ambos tipos de techumbres»(Guerin, 2003, 230-232). El criterio distintivo que aplican para diferenciar restos de los semipisos y primeras plantas de restos de la techumbre en los niveles de derrumbe ibéricos, no es el grosor de la capa o capas de tierra aplicadas por encima del entramado, sino la solidez del propio entramado. Así, las improntas de rollizo grueso (no menos de 5 $\mathrm{cm}$ de diámetro) dispuestas en paralelo y relativamente juntas, y con una cara lisa, responden, a su juicio, a una superficie cuya finalidad era ser pisada, probablemente un primer piso. Por el contrario, las improntas de romero, más ligeras, destinadas a cubrir vanos, pertenecerían a las cubiertas. Dependiendo del tipo de improntas halladas en los derrumbes, se podría pues, inferir la existencia, o no, de una primera planta en la casa.

Los fragmentos recuperados del Barranc de Gàfols muestran improntas de vigas de madera de sección circular de pequeño diámetro, entre 12 y $15 \mathrm{~cm}$, y muy juntas entre sí (Fig. 30), y muchos de los fragmentos de barro presentan una de sus caras planas, lo que a juicio de los investigadores a cargo del yacimiento, sería interpretable como vestigios de la segunda capa de barro, agua y paja aplicada sobre el encañizado de las techumbres para impermeabilizarlas (Morer et alii, 2001, 161-162). La misma interpretación tendemos a darle a los números 6 y 7 del catálogo de muestras presentado aquí (Figs. 12 y 13). Por otra parte, como hemos visto, es posible distinguir arqueológicamente los restos del derrumbe de la cubierta de los propios muros, por la ubicación de un estrato de descomposición orgánica, ocasionalmente restos de madera carbonizada, y presencia de fragmentos con improntas (Chausserie-Laprée y Nin, 2001, 145, fig. 19). El yacimiento presenta una estratigrafía nítida del proceso 
de destrucción de un hábitat de la Edad del Hierro a causa de un incendio). Lo que, a nuestro juicio, no es tan sencillo de discernir, es la pertenencia de los fragmentos de improntas al tejado de las estructuras o a los semipisos y primeras plantas.

Aplicando a los testimonios del Cerro de la Cruz los criterios antes mencionados, el grosor de la capa de barro no sería un criterio diferenciador pues, tanto una primera planta como el propio tejado precisarían, a nuestro juicio, de una consistencia considerable, una para pisar sobre ella con seguridad, y el otro fundamentalmente para garantizar la solidez e impermeabilidad del cubrimiento de la casa. De hecho, tanto los estudios basados en la evidencia arqueológica, como las hipótesis de reconstrucción de hábitats ibéricos basados en los datos obtenidos en excavaciones, tienden a fijar un grosor de entre 10 y $15 \mathrm{~cm}$ para las planchadas de barro, agua y paja que constituían el cierre de las cubiertas y pisos en alto (Belarte, 1997, 89; Bonet, Díez y Rubio, 2001, 86; Guerin, 2003, 230; Pou et alii, 2001, 105-106).

Las improntas de rollizo de gran diámetro, con cañizo cruzado a mitad de la pella de barro, con una cara lisa, y dispuestas muy juntas, bien podrían pertenecer también al tejado y no sólo a una primera planta. Hemos de tener en cuenta aquí la cuestión de la inclinación de las cubiertas, que ha generado no poca controversia. Si las cubiertas eran planas, como parece deducirse del urbanismo del Cerro de la Cruz, que aprovecha el escalonamiento del terreno para acceder de una casa a otra, resulta probable, por tanto, que estuvieran también destinadas a ser pisadas, incluso que se instalaran sombrajos también fabricados de cañizo, habilitándolas como verdaderas terrazas. Por otra parte, la técnica y materiales de construcción de las primeras plantas y de los tejados, eran esencialmente las mismas. La única solución al problema estribaría, pues, en el contexto estratigráfico. A día de hoy, no contamos con datos suficientes para distinguir, en el Cerro de la Cruz, un tipo de improntas de otras y asignarlas a una $u$ otra estructura dentro de las unidades de habitación, a pesar de la claridad con que se ha podido documentar estratigráficamente el incendio que asoló el poblado.

\section{PRIMEROS TESTIMONIOS DE CESTERÍA EN EL CERRO DE LA CRUZ (NOS CAT. 2, 12 Y 14)}

Hasta ahora hemos analizado detenidamente una serie de muestras que nos ayudan a entender la manera de edificar en el Cerro de la Cruz. Los elementos vegetales, fueron, como hemos podido comprobar, de una importancia crucial. Sin embargo, no sólo se emplearon diferentes tipos de vegetación arbustiva y de ribera para la construcción de techumbres, ya que otro tipo de elementos vegetales se emplearon con profusión en la manufactura de útiles vinculados al almacenamiento de excedente, objetos ornamentales y vestimenta.
El rico registro arqueológico del Cerro de la Cruz nos ha legado, también, un repertorio de vestigios de cestería e industria textil cuantitativamente menor que el de las improntas arquitectónicas, pero de innegable interés, que ofrece un claro testimonio de lo expuesto anteriormente. Las muestras de cestería documentadas han aparecido, al igual que las ya estudiadas de arquitectura, en forma de improntas en negativo impresas sobre fragmentos de barro endurecido que pertenecían a los muros, cubiertas y primeras plantas de las viviendas ibéricas. Por ello las presentamos también aquí.

Conviene recordar, en este punto, que la casa ibérica era concebida como una vivienda-almacén y centro de producción de recursos básicos. En este sentido, el utillaje elaborado a base de trama y trenzado de elementos vegetales, como el esparto, convivía con los materiales cerámicos para asegurar el almacenamiento y preservación de alimentos y otros recursos. Las improntas de cestería del Cerro de la Cruz se pueden diferenciar razonablemente bien de las de elementos constructivos, es por ello que consideramos que este trabajo quedaría incompleto sin el estudio de estas últimas. Dejaremos, en cambio, el análisis de vestigios de industria textil documentados para futuros trabajos.

Hasta fechas muy recientes la cestería ha compartido, junto con la cerámica, un destacado protagonismo en las labores de transporte y almacenaje. El carácter perecedero de los materiales empleados en su factura ha supuesto que en muy pocas ocasiones se hallen vestigios de su uso, y consecuentemente sea un género de objeto muy desconocido en comparación con otros materiales vinculados igualmente a la producción de contenedores, caso particular de la cerámica. Las condiciones de destrucción y abandono del yacimiento del Cerro de la Cruz han favorecido la conservación de algunos de ellos. Así, hemos podido documentar testimonios de cestería en el poblado: merced a la impronta o negativo dejado por estos objetos sobre superficies terrosas (producto a su vez del derrumbe de las viviendas con ocasión del mencionado ataque), o bien merced a la conservación del propio objeto, carbonizado por efecto del fuego que consumió el poblado. Entre los primeros destaca un conjunto de varios fragmentos de tierra compactada con presencia de improntas de urdimbre, aparentemente de cestería, hallado en los niveles de derrumbe de las Estancias IV y V (Figs. 2 y 4; Fig. 7). A los segundos (objetos carbonizados) pertenecen las muestras cat. 12 (Fig. 22) y 14 (Figs. 26-28), hallados ambos en la Estancia III.

Los fragmentos de improntas, así como uno de los restos carbonizados muestran entramados complejos y repetitivos formados por haces (o ramales) de fibras que se entrecruzan perpendicularmente entre sí. El número de fibras que compone cada ramal es difícil de determinar, por la modesta conservación de los testimonios, pero se estima en torno a 6-8 fibras por ramal. La anchura de estos ramales, en los testimonios conservados, oscila entre los 5,5 y 7,5 $\mathrm{mm}$. 
Estos ramales se van cruzando de una forma definida para ir generando el entramado deseado. En los dos mencionados ejemplos (cat. 02 y 14) el entramado elegido es el mismo, conocido en terminología textil como «sarga» o "cestería cruzada en sargas» (Alfaro Giner, 1984, 155), y con una secuencia $2 / 2$, esto es, en la que cada ramal salta dos transversales, se sumerge bajo otros dos, vuelve a saltar dos, y así sucesivamente («2/2 twill» según Gleba, 2008, 40). Además, el ramal que se dispone en paralelo a éste forma una secuencia idéntica, pero comenzando un escalón o ramal perpendicular más avanzado. Lo mismo sucede a su vez con el ramal dispuesto al lado de éste, y sucesivamente. La longitud de los tramos de ramales visibles - esto es, antes de que se sumerjan bajo otros ramales- es de en torno al doble de su anchura, en tanto saltan sobre dos ramales perpendiculares antes de sumergirse. Por tanto son tramos de en torno a 11-15 mm de longitud. El aspecto final del conjunto resulta en un característico movimiento diagonal o zigzagueante. Todos los testimonios de cestería documentados en el yacimiento, tanto en forma de impronta como restos carbonizados, siguen este mismo modelo de entramado.

En cuanto al material de factura de estos entramados todo apunta a que se trate del esparto. En primer lugar, el grosor de las fibras documentadas (en torno a $1 \mathrm{~mm}$ ) así lo sugiere; por otro lado, el esparto (Stipa tenacissima) fue un material usado con profusión en el mundo Antiguo, tanto en Grecia como Roma y, sobre todo, en la península ibérica, tal y como confirman las fuentes y su abundantísima presencia, aún hoy día y de forma silvestre, en el centro y mitad meridional de la península (Liv. XXII, 60,6; Ateneo, 206f; Mela II, 86; Strab. III, 49 (160); Aul. Gel., Noctes Atticae XVII, 3).

Es particularmente llamativo el empleo del sobrenombre Spartaria para la ciudad de Carthago Nova: Plin. 94; Ap., Iber. 12; Hidac. 21.86, It. Ant. 396,3, Isid., Hist. Vand. 73. Entre estas fuentes destaca Plinio quien, al hablar de las poblaciones montañesas de la zona de Cartagena, indica que empleaban el esparto para confeccionar «sus lechos, su fuego, su alumbrado, sus zapatos y los pastores sus trajes» (Nat. Hist. XIX, 27, 7-9, ver Blázquez, 1971, y Alfaro Giner, 1975, passim).

Por su parte, la arqueología demuestra el empleo asiduo de este material en la península ibérica para la fabricación de contenedores al menos desde el Calcolítico (Alfaro Giner, 1984, 59 y ss), por ejemplo en la Cueva de los Murciélagos (Granada), cuya datación se establece en torno al 3400 a.C. (Alfaro Giner, 1980, $110 ; 1973,193)$. O también para la fabricación de esterillas circulares, como se documenta en Peña Negra (Alicante), yacimiento del Bronce Final (Papí Rodes, 1992-4, passim).

Documentamos fragmentos de pleita de esparto que siguen el mismo entramado en sargas, antes mencionado, en el pecio de El Sec (Mallorca) datado entre los años 360-350 a.C. (Alfaro Giner, 1984, 156, $\mathrm{n}^{\circ}$ 5), y en una mina de Mazarrón (Murcia) (Alfaro Giner,
1984, 158, no 18), de cronología presumiblemente alto-imperial. Por fin, nos llama la atención el hecho de que todas las características que venimos mencionando son plenamente correspondientes con las técnicas empleadas en la actualidad, en ámbitos rurales, para el trabajo del esparto, lo que sirve de refrendo a la identificación de los restos conservados como tal.

No hay indicios en los restos documentados de majado o mazado, esto es, del ablandamiento de las fibras por percusión con una maza, que sabemos se aplica para lograr una mayor flexibilidad y que se documenta en la península ibérica desde la Edad del Cobre (Alfaro Giner, 1980, 111). Las fibras por tanto conservan su forma original y su sección circular, lo que redunda en su mayor resistencia, así como en la del objeto que conforman.

Por último, es preciso señalar que ambas piezas (nos. cat. 02 y 14) muestran lo que parecen ser los límites de la pleita, lo que podría ofrecer información interesante acerca de la morfología de este tipo de objetos. En el caso de la pieza $n^{\circ} 02$, se aprecia que los ramales alcanzan un punto a partir del cual todos ellos giran un mínimo de 90 grados, y en la misma dirección. Se trata, muy probablemente, del borde o límite del objeto, a partir del cual los ramales han de girar sobre sí mismos, bien para volver a entrelazarse en la misma pleita de la que surgen, bien para unirse a una segunda pleita. Lo primero genera un límite para una superficie plana, lo segundo la unión de dos superficies (por ejemplo, la base y paredes de un cesto). Lamentablemente el estado de conservación de los restos nos impide determinar cuál es el caso aquí.

Contamos, también, con restos carbonizados adheridos a la pared interna de un contenedor de aleación de cobre de tendencia hemiesférica (n. cat. 12, Fig. 22). Este caldero profundo, similar a un lebes, aparentemente carece de asas. Dado que se encuentra muy deformado, su diámetro varía según medición entre 38 y $47 \mathrm{~cm}$. El mal estado de conservación de los restos de carbón del interior del caldero nos impide identificarlos con seguridad, pero parecen corresponder a fibras vegetales, quizá esparto, y se intuye una disposición ordenada, en entramado. De confirmarse, se trataría de una posible pieza de esparto en el interior de un recipiente metálico.

El contenedor fue hallado, muy fragmentado y aplastado, en uno de los estratos de colmatación (US 1264) del interior de la Estancia III. Los materiales hallados en este mismo estrato son riquísimos, e incluyen un cuenco caliciforme, un plato ibérico, una cuenta de collar de pasta vítrea de color azul (semejante al color de la azurita) con irisaciones, un cuenco ibérico, dos ollas ibéricas; uno o dos lebrillos, al menos tres pithoi, un vaso cerrado, restos informes de plomo de un objeto indeterminado, un tonelete ibérico, fragmentos de hierro de función incierta, un ánfora ibero-púnica, un cuchillo de hierro afalcatado, dos cubiletes ibéricos, dos arandelas de hierro, un hacha o tajador ibérico de hierro y hasta 18 pesas de telar. Todos estos materiales 
fueron hallados en el estrato más superficial de cuantos colmatan la mencionada Estancia III. En niveles inferiores, correspondientes al nivel de uso de la estancia, hallamos hasta 41 ánforas de tipo ibero-púnico cuyo interior ha revelado importantes concentraciones de semillas de trigo y acebuche. También vajilla ibérica: platos, cuencos, ollas, pithoi, un tonelete ibérico, herramientas de hierro, una cuenta de collar de hueso trabajado, más pesas de telar, dos cuchillos, y un posible mueble con abrazaderas de hierro.

La impresión que proporciona esta información parece indicar la presencia de dos o más niveles de altura en el edificio ibérico, a juzgar por el gran volumen de restos de material constructivo que colmataban la sala (en su mayoría adobe descompuesto), y por la presencia de objetos a distintas cotas. Como venimos diciendo, el contenedor de aleación de cobre con restos de pleita de esparto se halló en los estratos superiores, por lo que muy probablemente se hallara depositado en un piso superior.

En suma, una estancia dotada de una o más alturas o pisos y colmada de materiales diversos cuya función muy probablemente fuera la del almacenaje de víveres y útiles para el piso inferior, y como vivienda, taller de telar y acaso cocina, para un más que probable nivel o piso superior.

\section{CONCLUSIONES}

Las muestras del Cerro de la Cruz reflejan un empleo prolijo de elementos vegetales en la configuración de la cultura material necesaria para la vida cotidiana en la Baja Época Ibérica. Estamos en disposición de confirmar que las soluciones arquitectónicas para la construcción de techumbres y primeras plantas coincidían, en sus aspectos básicos, con las documentadas en el área ibérica levantina y catalana. El sistema de envigado no está tan bien documentado como en algunos yacimientos estudiados, tan sólo contamos, con dos posibles pero dudosas muestras de improntas de vigas, quizá de sección cuadrangular, aunque sí podemos constatar que los encañizados, de diverso grosor, con toda probabilidad compuestos de cañas comunes y carrizo, más fino, eran un elemento indispensable en la fabricación de las cubiertas de las casas del poblado.

Asimismo, es evidente el empleo de tierra mezclada con agua y paja para aplicarla por encima del encañizado; probablemente se dispusiese, además, más de una capa, a juzgar por el grosor de las pellas de barro endurecido recuperadas tras el incendio. Sin embargo, a pesar de analizar con cierto detalle las muestras, teniendo siempre en cuenta sus contextos arqueológicos, sigue estando presente una gran dificultad de interpretación que no podemos dejar de señalar a modo de conclusión.

La distinción entre las improntas pertenecientes a vegetales utilizados en elementos constructivos y aquellas correspondientes a artefactos, se puede establecer con bastante claridad. No ocurre lo mismo, como hemos podido comprobar, cuando tratamos de esclarecer la naturaleza exacta de las improntas de elementos constructivos y distinguir a qué parte de las estructuras de habitación pertenecieron los bloques de barro endurecido sobre los que quedaron impresas las marcas. Efectivamente, el tamaño, sección, diámetro y disposición de las improntas, nos dan indicios a tener en cuenta para su clasificación. Por otra parte, las dimensiones de los fragmentos de barro endurecido que alojan las improntas son también indicativos de la naturaleza y función originales de los fragmentos estudiados. Según estos parámetros de estudio, contamos con un total de once muestras de fragmentos de barro con improntas arquitectónicas, de ellas: una es indeterminada, al menos dos parecen pertenecer a adobes con restos de paja y cañizo que se quedaron adheridos a las piezas en el proceso de secado, otras dos podrían contener improntas de vigas o elementos lígneos, y las seis restantes presentan claras huellas de cañas, gruesas y finas dispuestas de forma paralela o entrecruzada.

Los resultados de las excavaciones del Cerro de la Cruz han constatado que las unidades de vivienda constaban, en su mayoría de más de un piso (Quesada, Kavanagh y Moralejo, 2010, 39, fig. 12). La naturaleza y aprovechamiento del terreno, el grosor de los muros, las cotas y secuencia de deposición de algunos materiales, sobre todo cerámicos, así como la abundancia de improntas sobre los niveles de uso del pavimento, y bajo el derrumbe de los muros, corroboran esta hipótesis. Ahora bien, la clasificación y diferenciación exacta de improntas que podrían pertenecer a primeras plantas y altillos, y las correspondientes a elementos de cubiertas resulta, a la luz de los datos disponibles, una empresa extremadamente compleja y delicada, por las razones expuestas más arriba. Por tanto, este estudio tan sólo pretende, por ahora, presentar estos testimonios y señalar los indicios que nos han conducido a interpretar unos y otros fragmentos de diversas maneras. Hemos de aguardar a la aparición de más pruebas que puedan confirmar, matizar y enriquecer la información disponible a día de hoy. Con todo, creemos que el conjunto que hemos estudiado aquí supone, per se, una enriquecedora aportación al panorama de la arquitectura ibérica dada la generalizada escasez de evidencias arqueológicas de esta índole en los yacimientos de todo el período ibérico, especialmente en el Ibérico Final, por lo que su estudio proporciona valiosos elementos para futuras interpretaciones y paralelos para nuevos hallazgos.

En cuanto a los testimonios de cestería hallados en el yacimiento, debemos reseñar la constatación del empleo de superficies (pleitas) -formadas por entramados de fibras de esparto- por parte de los habitantes del poblado de Baja Época Ibérica. La función exacta de estas pleitas es difícil de determinar, pero con toda probabilidad formaran parte de útiles domésticos de carácter contenedor; esto es, objetos de cestería. Nos llama la atención el hecho de que el patrón de 
entramado elegido es en todo caso el mismo, conocido como «en sargas» y con una alternancia o secuencia de ramales de $2 / 2$, ya definida.

Dos de los tres testimonios de cestería hallados corresponden al interior de una estancia (III) cuya función muy probablemente fuera la de almacenamiento, como prueba la gran acumulación de objetos y contenedores en ella hallados, lo que sugiere que estos ejemplos de cestería igualmente podrían cumplir una función de almacenaje. El tercer testimonio de cestería pertenece a una estancia (V) dotada de dos grandes molinos rotatorios ibéricos, de lo que quizá podamos deducir una participación de estos cestos en los procesos de almacenamiento o molienda tanto del trigo como de la harina resultante. Lo exiguo de estos vestigios nos impide extraer mayores conclusiones, pero permite por un lado constatar su empleo y nos invita, a un tiempo, a reconsiderar el protagonismo e importancia que los objetos de cestería pudieron haber tenido en la cultura ibérica, poco y mal conocidos como consecuencia de la escasez de testimonios.

\author{
Javier Moralejo Ordax \\ Dpt. de Ciències de 1'Antiguitat i de l'Edat Mitjana \\ Facultat de Filosofia i Lletres, Edifici B \\ Universitat Autònoma de Barcelona \\ 08193 Bellaterra \\ javiersantiago.moralejo@uab.cat \\ Dr. Eduardo Kavanagh de Prado \\ Prof. Dr. Fernando Quesada Sanz \\ Dpto. de Prehistoria y Arqueología \\ Facultad de Filosofía y Letras \\ Universidad Autónoma de Madrid \\ Campus de Cantoblanco \\ 28049 Madrid \\ eduardo.kavanagh@gmail.com \\ fernando.quesada@uam.es
}

\section{BIBLIOGRAFÍA}

ABAD CASAL, L., 1996: «Modelos de hábitat en el Mundo Ibérico. Una década de investigaciones», Revista de Estudios Ibéricos, 2, 123-145.

ABAD, L. y SALA, F., 1993: El poblado ibérico de El Oral (San Fulgencio, Alicante), Valencia.

ABAD, L. y SALA, F., 2001 (eds.): Poblamiento Ibérico en el Bajo Segura: El Oral (II) y La Escuera, Bibliotheca Archaeologica Hispanica 12, Madrid.

ALFARO GINER, C., 1975: «El cultivo del esparto en el s. I a.C.: consideraciones acerca de un pasaje de Varrón», en Actas de las I Jornadas de Metodología aplicada a las Ciencias Históricas, I, Prehistoria e Historia Antigua, 191-196, Santiago de Compostela.

ALFARO GINER, C., 1980: «Estudio de los materiales de cestería procedentes de la cueva de los Murciélagos (Albuñol, Granada)», Trabajos de prehistoria, 37, 109-139.

ALFARO GINER, C., 1984: Tejido y cestería en la Península Ibérica: historia de su técnica e industrias desde la prehistoria hasta la romanización, Bibliotheca Praehistorica Hispana 21, Madrid.
ARCELIN, P. y BUSCHENSCHUTZ, O., 1985: «Les données de la protohistoire», en J. Lasfargues (dir.), Achitecture de terre et de bois, DAF 2, 15-28, Paris.

ASENSIO ESTEBAN, J. A., 1995: «Arquitectura de tierra y madera en la protohistoria del Valle Medio del Ebro y su relación con la del Mediterráneo», Caesaraugusta, 71, 23-56.

BELARTE, M. C. ET ALII., 1994: «L'assentament protohistòric del Barranc de Gàfols (Ginestar, Ribera d'Ebre)», Tribuna d'Arqueologia, 1992-1993, 63-72.

BELARTE, M. C., SANMARTÍ, J. y SANTACANA, J., 1994: «El asentamiento protohistórico del Barranc de Gàfols (Ginestar, Ribera d'Ebre, Tarragona)», 1 Congresso de Arqueología Peninsular (Porto, 12-18 de Outubro de 1993), vol. III, 231-243, Porto.

BELARTE FRANCO, M. C., 1997: Arquitectura domèstica $i$ estructura social a la Catalunya protohistórica, Arqueomediterrània, 1, Barcelona.

BELARTE FRANCO, M. C., 1999-2000: «Sobre el uso del barro en la protohistoria del Bajo Aragón: estudio de materiales conservados en el Museu d'Arqueologia de Catalunya-Barcelona», Kalathos, 18-19, 65-93.

BELARTE FRANCO, M. C., 2001: "Les tècniques constructives al mon ibèric», en M. C. Belarte et alii (eds.), Tècniques constructives d'època ibérica i experimentació arquitectònica a la Mediterrània, Actes de la Reuniò Internacional d'Arqueologia de Calafell (Calafell, 20, 21 i 22 de gener del 2000), Arqueo Mediterrània, 6, 27 41. Barcelona.

BELARTE, M. C., NOGUERA, J. y SANMARTÍ, J., 2002: «El jaciment del Castellot de la Roca Roja (Benifallet, Baix Ebre). Un patró d'hàbitat ibèric en el curs inferior de l'Ebre», I Jornades d'Arqueologia Ibers a l'Ebre. Recerca i interpretació, 89-110, Tivissa.

BELARTE, M. C., BONET, H. y SALA, F., 2009: «L'espai domèstic i l'organització de la societat ibèrica: els territoris de la franja mediterrània», Arqueomediterrània, 11, 93-123.

BELARTE FRANCO, M. C., 2010: La casa ibèrica. De la construcció al us de l'espai, Barcelona.

BLÁZQUEZ MARTÍNEZ, J. Mª., 1971: «Economía de Hispania al final de la República romana y a comienzos del Imperio según Estrabón y Plinio», Revista de la Universidad de Madrid, 20, 57-143.

BONET, H. y GUERIN, P., 1989: «Techniques de construction et aménagement des espaces domestiques ibériques en région valencienne», en Habitats et structures domestiques en Méditerranée occidentale durant la Protohistoire (Arles-sur-Rhône), 128-132, Aix-en-Provence.

BONET, H; GUERIN, P. y MATA, C., 1994: «Urbanisme i habitatge ibèrics al País Valencià», Cota Zero, 10, 115-130.

BONET ROSADO, H., 1995: El Tossal de Sant Miquel de Llíria. La antigua Edeta y su territorio, Valencia.

BONET, H. y GUERIN, P., 1995: «Propuestas metodológicas para la definición de la vivienda ibérica en el área valenciana», en Ethno-Archeologie Médirerraénne, finalités, démarches et résultats (Madrid 1990), 85-104, Madrid. 
BONET, H; DÍES, E. y RUBIO, F., 2000: «Proyecto de área didáctica y de investigación arquitectónica. La construcción de una casa ibérica en la Bastida de Les Alcusses (Moixent, València)», en C. Mata i G. Pérez (eds.), III Reunió sobre economia en el mon ibèric (1999), Saguntum-PLAV, Extra 3, 431-439, Valencia.

BUCHSENSCHUTZ O., 1984: Structures d'habitats et fortifications del'Âge du Fer en France septentrionale, Memoires de la Societè Préhistorique Française 18, Paris.

BUCHSENSCHUTZ, O. y MORDANT C. (eds.), 2005: Architectures protohistoriques en Europe occidentale, $d u$ Néolithique final à l'âge du fer, Nancy.

BURILLO MOTOZA, F., 1985: «Introducción a los orígenes de la arquitectura de tierra en Aragón», Turia, I, 9-49, Teruel.

CARMONA, R., 2010: «La ocupación medieval andalusí del Cerro de la Cruz», en I. Muñiz y F. Quesada (eds), Un drama en tres actos. Dos milenios de ocupación humana en el Cerro de la Cruz (Almedinilla, Córdoba), OIKOS.Cuadernos monográficos del Ecomuseo del Río Caicena, 2, 109-125.

CHAUSSERIE-LAPREE, J. y NIN, N., 2001: «De la fouille à la mise en valeur: l'habitat protohistorique de l'Ille de Martigues», en, M. C belarte et alii (eds.), Tècniques constructives d'època ibérica i experimentació arquitectònica a la Mediterrània, Actes de la Reuniò Internacional d'Arqueologia de Calafell (Calafell, 20, 21 i 22 de gener del 2000), Arqueomediterrània, 6, 133-155.

CHAZELLES, C. A. DE., 1999: «A propos des murs en terre massive de Lattes: la bauge, un mode de construction protohistorique», Lattara, 12, 229-254.

CHAZELLES, C.A. DE., 2001: «Les Techniques de construction protohistoriques en Gaule méridionale», en, M. C. Belarte et alii (eds.), Tècniques constructives d'època ibérica i experimentació arquitectònica a la Mediterrània, Actes de la Reuniò Internacional d'Arqueologia de Calafell (Calafell, 20, 21 i 22 de gener del 2000), Arqueomediterrània, 6, 11-27.

DUQUE ESPINO, D.M., 2004a: La gestión del paisaje vegetal en la Prehistoria Reciente y Protohistoria en la Cuenca Media del Guadiana a partir de la antracología, Tesis Doctoral, Servicio de publicaciones de la Universidad de Extremadura, Cáceres, [accesible en Internet en formato en http://dialnet.unirioja.es/servlet/ tesis?codigo=199, último acceso 9 de Mayo de 2015].

DUQUE ESPINO, D.M. 2004b: «La madera en la construcción y adecuación del edificio de 'La Mata'», en A. Rodríguez Díaz (ed.), El edificio protohistórico de 'La Mata' (Campanario, Badajoz) y su estudio territorial, I, 345-384, Cáceres.

DUQUE ESPINO, D.M., 2005: «Aproximación al paisaje vegetal del orientalizante en la cuenca media del Guadiana a través de la Antracología y su integración con los datos paleoambientales», en S. Celestino y J. Jiménez (eds.), El Periodo Orientalizante, Anejos de AEspA, 35.2, 967-976, Madrid.

FATÁS, L. y CATALÁN, S., 2005:«La construcción con tierra en la protohistoria del Bajo Aragón: el caso de San Cristobal de Mazaleón», Saldvie, 5, 131-141.
FRANCÈS, J. y PONS, E., 1998: «L'habitat del bronze final i de la primera edat del ferro a Catalunya litoral i prelitoral», Cypsela, 12, 31-46.

GARCIA, D., 2000: «Économie et réseau urbain protohistoriques dans le nord-est du monde ibérique (Rousillon et Languedoc occidental) (VI-IIe s. av. J.-C.)», en C. Mata i G. Pérez (eds.), III Reunió sobre economia en el mon ibèric (1999), Saguntum-PLAV, Extra 3, 69-79, Valencia.

GENERA, M., 1995: El poblat prehistòric del Puig Roig del Roget (El Masroig, Priorat), Barcelona.

GONZÁLEZ DEL CAMPO, E., 2010: «La aldea de época emiral del Cerro de la Cruz. Una aproximación a su arquitectura y cultura material», en, I. Muñiz y F. Quesada (eds.), Un drama en tres actos. Dos milenios de ocupación humana en el Cerro de la Cruz (Almedinilla, Córdoba), OIKOS.Cuadernos monográficos del Ecomuseo del Río Caicena, 2, 125-141.

GUERIN, P., 2003: El Castellet de Bernabé y el horizonte ibérico pleno edetano, SIP, Serie de trabajos varios 101, Valencia.

HODARA, J.J., 2002: «L'architecture de l'habitat protohistorique: contraintes techniques», Actes des congrés nationnaux des societés historiques et scientifiques, 127, 65-76, Nancy.

LÓPEZ FLORES, I., 2010: «Los restos óseos humanos del Cerro de la Cruz», en I. Muñiz y F. Quesada (eds.), Un drama en tres actos. Dos milenios de ocupación humana en el Cerro de la Cruz (Almedinilla, Córdoba), OIKOS. Cuadernos monográficos del Ecomuseo del Río Caicena, 2, 97-103.

MALUQUER DE MOTES, J., 1986: Arquitectura i urbanisme ibèrics a Catalunya, Barcelona.

MORER, J. ET ALII., 2001: «El laboratori d'arquitectura protohistórica de la Universitat de Barcelona, en, M. C. Belarte et alii (eds.), Tècniques constructives d'època ibérica i experimentació arquitectònica a la Mediterrània, Actes de la Reuniò Internacional d'Arqueologia de Calafell (Calafell, 20, 21 i 22 de gener del 2000), Arqueomediterrània, 6, 157-180.

MUÑIZ, I. y QUESADA, F., (eds.) 2010: Un drama en tres actos. Dos milenios de ocupación humana en el Cerro de la Cruz (Almedinilla, Córdoba), OIKOS. Cuadernos monográficos del Ecomuseo del Río Caicena, 2, Córdoba.

MUÑÍZ JAEN, I., 2010: «La puesta en valor del Cerro de la Cruz», en I. Muñiz y F. Quesada (eds.), Un drama en tres actos. Dos milenios de ocupación humana en el Cerro de la Cruz (Almedinilla, Córdoba), OIKOS. Cuadernos monográficos del Ecomuseo del Río Caicena, 2, 165-175.

PAPÍ RODES, C., 1992-4: «Improntas de esterillas en cerámicas del Bronce Final de la Peña Negra (Crevillente, Alicante) (Campañas de 1983 y 1984)», Lvcentvm, XIXIII, 39-49.

PELLICER, M. y SCHÜLE, W., 1962: El cerro del Real (Galera, Granada). Excavaciones arqueológicas en España, Madrid.

PINIGRE, J. F. y NICOLAS, T., 2002: «Structures arasées? Architectures fugaces: l'exemple de l'habitat du Bronze 
Final de Quitte (Haut-Saône)», Actes des congrés nationnaux des societés historiques et scientifiques, 127, 349-363, Nancy.

POU, J., SANMARTÍ, J. y SANTACANA, J., 1995: «La construcció del poblat ibèric d'Alorda Park o de les Toixoneres (Calafell, Baix Penedès)», Tribuna d'Arqueologia, 1993-1994, 51-62.

POU, J., SANTACANA, J., MORER, J., ASENSIO, D. y SANMARTÍ, J., 2001: «El projecte d'intepretació arquitectònica de la ciutadella ibèrica de Calafell (Baix Penedès)», en M. C. Belarte et alii (eds.), Tècniques constructives d'època ibèrica $i$ experimentació arquitectònica a la Mediterrània, Actes de la Reunió Internacional d'Arqueologia de Calafell (Calafell, 20, 21 i 22 de gener del 2000), Arqueomediterrània, 6, 95-117.

QUESADA, F., KAVANAGH, E. y MORALEJO, J., 2010: «El asentamiento de época ibérica en el Cerro de la Cruz», en I. Muñiz y F. Quesada (eds.), Un drama en tres actos. Dos milenios de ocupación humana en el Cerro de la Cruz (Almedinilla, Córdoba), OIKOS. Cuadernos monográficos del Ecomuseo del Río Caicena, 2, 75-95.

QUESADA, F., KAVANAGH, E. y LANZ, M., 2014: «Los molinos del yacimiento del Cerro de la Cruz (Almedini1la, Córdoba): clasificación y análisis de los ejemplares de época ibérica y emiral», Spal, 23, 83-118.

QUESADA, F., MORALEJO, J. y KAVANAGH, E., 2010: «Una historia en sí misma: las investigaciones en el Cerro de la Cruz», en I. Muñiz y F. Quesada (eds.), Un drama en tres actos. Dos milenios de ocupación humana en el Cerro de la Cruz (Almedinilla, Córdoba), OIKOS. Cuadernos monográficos del Ecomuseo del Río Caice$n a, 2,31-45$.

QUESADA, F., MUÑIZ, I. y LÓPEZ, I., 2014: «La guerre et ses traces:destruction et massacre dans le village ibérique du Cerro de la Cruz (Cordove) et leur contexte historique au $\mathrm{II}^{\mathrm{e}}$ s. a. C», en F. Cadiou y M. Navarro (eds.), Conflits et sociétés en Hispanie à l'époque de la conquête romaine (IIIe-Ier s. a. C), 231-271, Bordeaux.

REAL DECRETO 630/2013, de 2 de agosto, por el que se regula el Catálogo español de especies exóticas invasora, $B O E$, n. 185, 03-02-2013, 56764-56786.
SÁNCHEZ GARCÍA, A., 1999a: «Las técnicas constructivas con tierra en la arqueología prerromana del País Valenciano», Cuadernos de Prehistoria y Arqueología Castellonense, 20, 161-188.

SÁNCHEZ GARCÍA, A., 1999b: «Aproximación a la arquitectura doméstica del País Valenciano: de la Edad del Bronce al Mundo Ibérico», R. de Balbín y P. Bueno (coords.), Actas del II Congreso de Arqueología Peninsular (Zamora, 1996), 389-404, Zamora.

SANMARTÍ, J., 1998: «La Casa Ibérica», en C. Aranegui, J.P. Mohen y P. Rouillard (eds.), Los Íberos: Príncipes de Occidente, 92-95, Barcelona.

SANMARTÍ, J. ET ALII., 2000: L'assentament del bronze final i primera edat del ferro del Barranc de Gàfols (Ginestar, Ribera d'Ebre), Arqueomediterrània, 5, Barcelona.

SANMARTÍ, J. ET ALII., 2012: «El Castellet de Banyoles (Tivissa): Una ciudad ibérica en el curso inferior del Ebro», Archivo Español de Arqueología, 85, 43-63.

SANZ ELORZA, M., DANA SÁNCHEZ, E.D. y SOBRINO VESPERINAS, E. (eds.), 2004: Atlas de las plantas alóctonas invasoras en España, Madrid.

VAQUERIZO, D., 1990: El yacimiento ibérico del Cerro de la Cruz (Almedinilla, Córdoba). Avance a su Excavación Arqueológica Sistemática, Córdoba.

VAQUERIZO, D., MURILLO, J.F. y QUESADA, F., 2001: Protohistoria y romanización en la Subbética Cordobe$s a$, Sevilla.

YAÑEZ CAMACHO, C., 2010: «Evolución del paisaje vegetal del Cerro de la Cruz», en: I. Muñiz y F. Quesada (eds.), Un drama en tres actos. Dos milenios de ocupación humana en el Cerro de la Cruz (Almedinilla, Córdoba), OIKOS.Cuadernos monográficos del Ecomuseo del Río Caicena, 2, 103-109.

VAQUERIZO, D., QUESADA, F. y MURILLO, J.F., 2001: Protohistoria y romanización en la Subbética Cordobe$s a$, Sevilla.

ZAMORA MERCHÁN, M., 2010: «El territorio y el poblado del Cerro de la Cruz», en: I. Muñiz y F. Quesada (eds.), Un drama en tres actos. Dos milenios de ocupación humana en el Cerro de la Cruz (Almedinilla, Córdoba), OIKOS.Cuadernos monográficos del Ecomuseo del Río Caicena, 2, 49-67. 